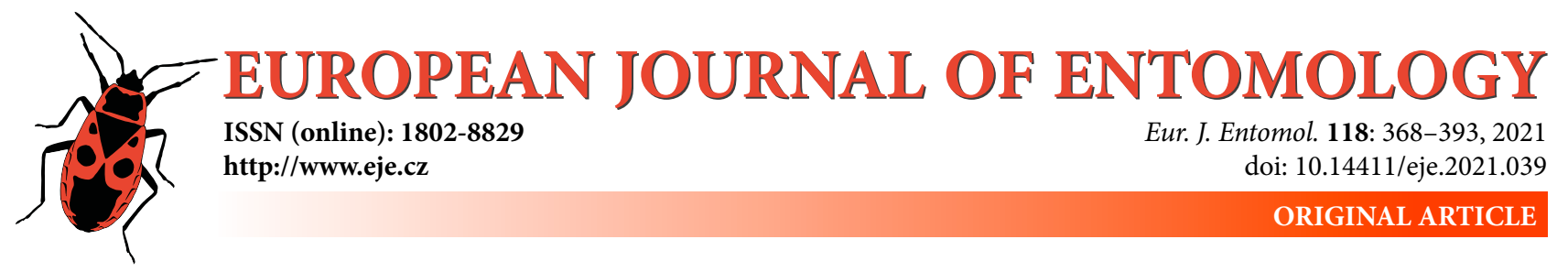

\title{
Taxonomic revision of the highly threatened Eumerus tricolor species group (Diptera: Syrphidae) in Southeast Europe, with insights into the conservation of the genus Eumerus
}

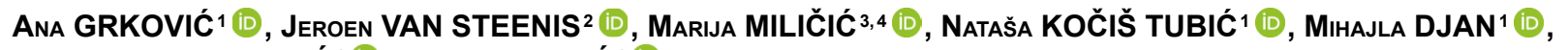 \\ SNEŽANA RADENKOVIĆ ${ }^{1}$ (D) and ANTE VUJIĆ ${ }^{1}$ (D) \\ ${ }^{1}$ University of Novi Sad, Faculty of Sciences, Department of Biology and Ecology, Trg Dositeja Obradovića 2, 21000 \\ Novi Sad, Serbia; e-mails: ana.grkovic@dbe.uns.ac.rs, natasa.kocis@dbe.uns.ac.rs, mihajla.djan@dbe.uns.ac.rs, \\ ante.vujic@dbe.uns.ac.rs, snezana.radenkovic@dbe.uns.ac.rs \\ ${ }^{2}$ Naturalis Biodiversity Center, Leiden, \% Hof der Toekomst 48, 3823 HX Amersfoort, The Netherlands; \\ e-mail: jvansteenis@syrphidaeintrees.com \\ ${ }^{3}$ Laboratory for Biosystems Research, BioSense Institute - Research Institute for Information Technologies in Biosystems, \\ University of Novi Sad, Dr. Zorana Đinđića 1, 21000 Novi Sad, Serbia; e-mail: marija.milicic@biosense.rs \\ ${ }^{4}$ LIBRe - Laboratory for Integrative Biodiversity Research, Finnish Museum of Natural History, University of Helsinki, Helsinki, \\ Finland
}

Key words. Diptera, Syrphidae, Eumerus tricolor group, COI gene, hoverfly diversity, identification key, new species, lectotype, small habitats, national park, taxonomic revision

\begin{abstract}
The diversity in the Eumerus tricolor group, the largest group within the genus in Southeast Europe, is investigated. Two new, locally distributed species are described, E. crispus Vujić \& Grković, sp. n. from Serbia and E. nigrorufus Grković \& Vujić, sp. n. from Montenegro. In addition to Southeast European members, one related species E. arctus van Steenis, sp. $\mathrm{n}$. is described from Switzerland. We designate lectotypes for E. ovatus Loew, 1848, E. tarsalis Loew, 1848, E. tricolor (Fabricius, 1798 ) and E. varius Meigen, 1822. A map of the distribution of members of the E. tricolor group in Southeast Europe is provided. In addition, records from other parts of Europe are listed and an illustrated identification key to the SE European species of the $E$. tricolor group provided. We also study and discuss the significance of small habitat patches for the preservation of species of Eumerus, because the three species described in this paper are currently known from such patches.
\end{abstract}

ZooBank Article Registration: http://zoobank.org/urn:Isid:zoobank.org:pub:C7775F2D-BE7D-4032-9127-3EF91A4C8ED2

\section{INTRODUCTION}

In the genus Eumerus Meigen, 1822, one of the most species-rich hoverfly genera, the total number of species is constantly increasing in Southeast Europe (Balkan Peninsula with Aegean Islands) and currently includes 44 species (Grković, 2018). The species recorded in Southeast Europe belong to the following groups, identified on the basis of molecular markers (Chroni et al., 2017) and morphological similarity: Eumerus strigatus group (Speight et al., 2013; Chroni et al., 2017 as E. amoenus group; Grković et al., 2017), E. tricolor group (Chroni et al., 2017; Grković et al., 2017), E. clavatus group (Grković et al., 2017), E. minotaurus group (Chroni et al., 2017, 2018), E. barbarus group (Chroni et al., 2017 as E. sulcitibius group; van Steenis et al., 2017), E. ornatus group (Chroni et al., 2017), E. obliquus group (Smit et al., 2017), E. basalis group (Chroni et al., 2017), E. pulchellus group (Chroni et al., 2017),
E. olivaceus group (A. Vujić, unpubl., containing E. alpinus Rondani, 1857, E. olivaceus Loew, 1848 and E. nudus Loew, 1848) and E. torsicus group (S. Malidžan et al., unpubl., containing E. torsicus Grković \& Vujić, 2015 and $E$. aff. torsicus). Two species subgroups are also defined: $E$. bactrianus subgroup in the E. strigatus group (Grković et al., 2019a; Smit et al., 2020) and E. binominatus subgroup in the E. tricolor group (Grković et al., 2019b). The E. tricolor group, as defined by Chroni et al. (2017) based on COI mtDNA data and Grković et al. (2017) who provided a morphological diagnosis, includes a wide spectrum of species, but is clearly separated from other species groups by a set of unique apomorphic characters (radially striated basoflagellomere with clearly bounded fossette, katepisternum completely pilose and poorly developed anterior lobe on male epandrium). Most species of the E. tricolor group are characterized by partially or completely red abdominal 
tergites, a character that is absent in other groups of European species of Eumerus. Another character that occurs exclusively in this group (considering only the European species) but not in all species, are more or less separated eyes in the males. Eumerus tricolor group comprises about $30 \%$ of all Eumerus species in Southeast Europe, a total of 13 species, of which as many as nine of the 11 assessed are proposed to be assigned to one of the threatened categories in Europe, according to the IUCN (A. Grković, unpubl.).

The Balkan Peninsula, together with the Aegean islands, are considered to be a hoverfly hotspot (Vujić et al., 2001; 2016), because of the great diversity of habitats and plant species there. As the Mediterranean region is especially rich in bulbs (Blondel \& Aronson, 1999), it is not surprising that phytophagous hoverflies that feed on bulbs, such as Merodon Meigen, 1803 and Eumerus, are especially diverse in this region (Ståhls et al., 2009; Grković, 2018). However, there are several threats to hoverfly biodiversity in these regions, such as over-exploitation of natural resources (Rosser et al., 2002), climate change (Shen \& Ma, 2014) and habitat destruction and degradation (Haddad et al., 2015). The new EU Biodiversity strategy for 2030 (European Commision, 2020) proposes ambitious overall actions to minimize factors negatively affecting biodiversity and contribute to safeguarding it. One of the goals of the new strategy is the enlargement of existing Natura 2000 areas. Indeed, even though large reserves have a crucial role in conservation, it is important to remember that often well-preserved small patches of habitat might be biodiversity reservoirs (Wintle et al., 2019; Häkkilä et al., 2021), which is confirmed in the case of Eumerus species in Southeast Europe.

In this paper, we: (1) present data about the species of the E. tricolor group occurring in Southeast Europe, (2) describe three new species in this group; (3) provide an identification key for the species in this group, and (4) conduct a genetic analysis in order to delimit the species in this group. We also (5) discuss the significance of small patches of habitat for the preservation of Eumerus species.

\section{MATERIAL AND METHODS}

Terminology of morphological characters follows Thompson (1999). Terminology referring to male genitalia follows Doczkal (1996). Colour characters are described from dry-mounted specimens. Male genitalia were boiled in $10 \% \mathrm{KOH}$, rinsed in glacial acetic acid and alcohol and stored in microvials in glycerine, attached to appropriate specimens. Photographs were taken with a Nikon Coolpix D7100 digital camera attached to a Nikon SMZ 745T (Nikon Corporation, Tokyo, Japan) stereomicroscope and then processed in CombineZ 1.0 software (Hadley, 2012) and Adobe Photoshop CS3 V 10.0 software (Adobe Systems, San Jose, CA, USA).

All the material examined belongs to the following museums and entomological collections: AE - André van Eck, private collection, Tilburg, The Netherlands; CSCA - California State Collection of Arthropods, Department of Food \& Agriculture, Sacramento, California, USA; FSUNS - Department of Biology and Ecology, Faculty of Sciences, University of Novi Sad, Serbia; GP - Gerard Pennards, private collection, Amsterdam, The Netherlands; IRSNB - Institut Royal des Sciences Naturelles de Belgique, Brussels, Belgium; JD - Jos Dils, private collection,
Hoevenen, Belgium; JS - Jeroen van Steenis, private collection, Amersfoort, The Netherlands; MAegean - The Melissotheque of the Aegean, University of the Aegean, Mytilene, Greece; MCW Michael de Courcy Williams, private collection, Alexandroupoli, Greece; MNHN - National Museum of Natural History, Paris, France; MNHP - Museum of the Natural History of Montenegro, Podgorica, Montenegro; MZH - Zoological Museum of the Finnish Museum of Natural History, Helsinki, Finland; MZLU Zoological Museum, Lund University, Sweden; NBC - Naturalis Biodiversity Center, Leiden, The Netherlands; NHMW - Natural History Museum Vienna, Austria; SB - Sander Bot, private collection, Haren, The Netherlands; WS - Wouter van Steenis, private collection, Amersfoort, The Netherlands; ZISP - Zoological Museum, Russian Academy of Sciences, St. Petersburg, Russia; ZMHB - Museum of Natural History of the Humboldt University, Berlin, Germany; ZMUC - Zoological Museum, Natural History Museum of Denmark, University of Copenhagen, Copenhagen, Denmark.

In support of the morphological descriptions of species from the E. tricolor group, we sequenced and analysed mtDNA COI gene of 43 specimens. All samples used for genetic analyses are listed in Table S1. DNA voucher specimens are deposited in the insect collections of the FSUNS, MZH or MAegean. Total genomic DNA was extracted using two or three legs from each specimen, using the slightly modified SDS Extraction Protocol described by Chen et al. (2010). The target DNA regions, 3'-end and 5'-end of COI gene, were amplified using C1-J-2183 (alias Jerry) and TL2-N-3014 (alias Pat) primer pair (Simon et al., 1994) and LCO1490 and HCO2198 primer pair (Folmer et al., 1994). The PCR reactions were carried out according to Kočiš Tubić et al. (2018). Purification of the obtained PCR products was done using the Exonuclease I and FastAP Thermosensitive Alkaline Phosphatase enzymes (ThermoScientific, Lithuania). Clean products were sequenced with the forward primer on an ABI3730x1 Genetic Analyzer (Applied Biosystems, USA) at the Finnish Institute for Molecular Medicine (FIMM), Helsinki, Finland (http://www.fimm.fi) and by the Macrogen EZ-Seq service (Macrogen Europe, Amsterdam, The Netherlands). Sequences were aligned using the Clustal W algorithm (Thompson et al., 1994) as implemented in BioEdit version 7.2.5. (Hall, 1999). The sequences were edited for base-calling errors using the same BioEdit software and adjusted manually. The sequences of the 5 '-end of COI gene were trimmed to a length of $570 \mathrm{nt}$ and those of the 3'-end of COI gene to $720 \mathrm{nt}$. The final analysed dataset (concatenated sequences of 3'-end and 5'-end of COI gene) comprised $1290 \mathrm{nt}$. Phylogenetic tree construction was done using Maximum Parsimony (MP) and Maximum Likelihood (ML) analyses. The parsimony analysis was conducted using NONA (Goloboff, 1999), spawned with the aid of ASADO, version 1.85 (Nixon, 2008), using the heuristic search algorithm (settings: mult*1,000, hold 100 , max trees 100,000, TBR branch swapping). The ML tree was constructed using MEGA version 7.0 (Kumar et al., 2016). The GTRGAMMA model with evolutionarily invariable sites $(\mathrm{GTR}+\mathrm{G}+\mathrm{I})$ was determined as the best model for the analysed dataset using MEGA version 7.0 (Kumar et al., 2016). Clade support was estimated using nonparametric bootstrapping with 1,000 replicates. Both trees were rooted by Archimicrodon sp.

To map the distribution of 13 species of the E. tricolor group, only precise distributional data were used. We used museum and literature data, as well as a database of the Department for Biology and Ecology, University of Novi Sad, Serbia. If locality coordinates were available, they were checked for accuracy. Records containing only locality names were assigned coordinates using Google Earth (Google Inc, 2020). Distribution maps were created 

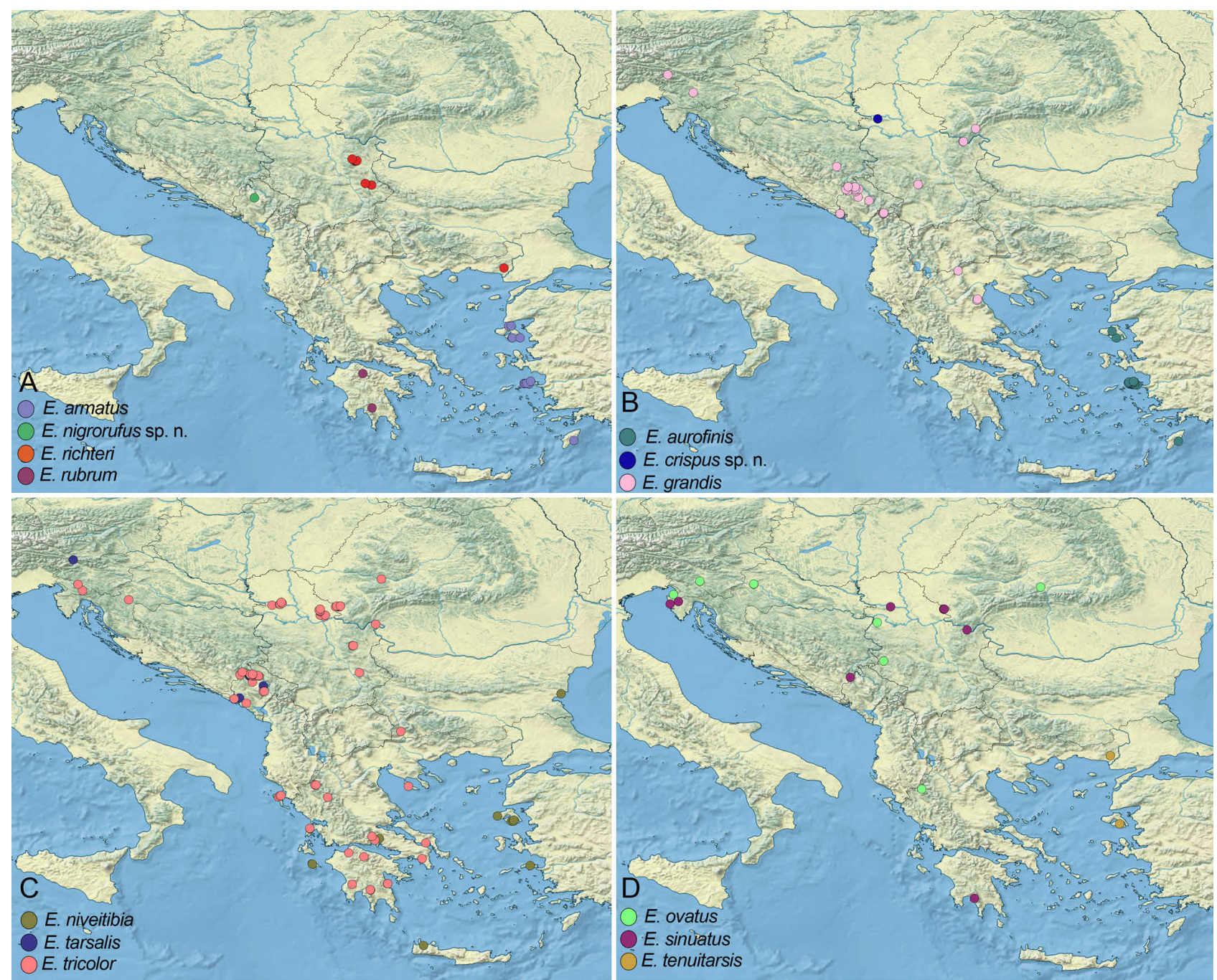

Fig. 1. Distribution of species of the Eumerus tricolor group in South East Europe. A - Eumerus armatus, Eumerus nigrorufus Grković et Vujić, sp.n., Eumerus richteri, Eumerus rubrum; B - Eumerus crispus Vujić et Grković, sp. n., Eumerus grandis, Eumerus aurofinis; C Eumerus niveitibia, Eumerus tarsalis, Eumerus tricolor, D - Eumerus ovatus, Eumerus sinuatus, Eumerus tenuitarsis.

using software GenGIS (v 2.5.3) (Parks et al., 2013). Map of the locality in Serbia, Grabovo, was created using the map found on a3.geosrbija.rs/katastar as the basemap. The map of localities in Montenegro, was created using the map found on www.nekretnine.co.me/me/digitalna-mapa.asp as the basemap. Both maps were processed in Adobe Photoshop CS3 V 10.0 software (Adobe Systems, San Jose, CA, USA).

\section{RESULTS AND DISCUSSION}

\section{Taxonomic account}

\section{Genus Eumerus Meigen, 1822}

Meigen, 1822: 202.

Type species: Syrphus tricolor Fabricius, 1798: 562 (Curtis design., 1839: 749).

\section{Eumerus tricolor species group}

Eumerus tricolor group sensu Chroni et al. (2017); Grković et al. (2017).

Diagnosis. Palearctic group of medium to large, mostly blackish species usually with partially or completely reddish tergites. Basoflagellomere radially striated, in females in some species very enlarged, apico-laterally with dis- tinctly bordered fossette. Eyes in males often slightly or remarkably dichoptic. Katepisternum completely pilose, in contrast to other congeneric species, in which separate dorsal and ventral pilose areas are present. Metafemur with two rows of strong and sharp spines posteroventrally. Posterior lobe on male epandrium simple, anterior lobe underdeveloped. Representatives of the E. binominatus subgroup can easily be recognized within this group by the extremely long and slender metaleg, which is most noticeable in males, where the width of the widest part of the metafemur is equal to or less than one fifth of the length of the metafemur.

In Southeast Europe, 13 representatives of the Eumerus tricolor group are recorded: E. armatus Ricarte \& Rotheray, 2012, E. aurofinis Grković, Vujić \& Radenković, 2015, E. crispus Vujić \& Grković, sp. n., E. grandis Meigen, 1822, E. nigrorufus Grković \& Vujić, sp. n., E. niveitibia Becker, 1921, E. ovatus Loew, 1848, E. richteri Stackelberg, 1960, E. rubrum Grković \& Vujić, 2017, E. sinuatus Loew, 1855, E. tarsalis Loew, 1848, E. tricolor (Fabricius, 1798) and E. tenuitarsis Grković \& Vujić, 2019 (Vujić \& Šimić, 1999; Ricarte et al., 2012; Grković et al., 2015; Grković et al., 


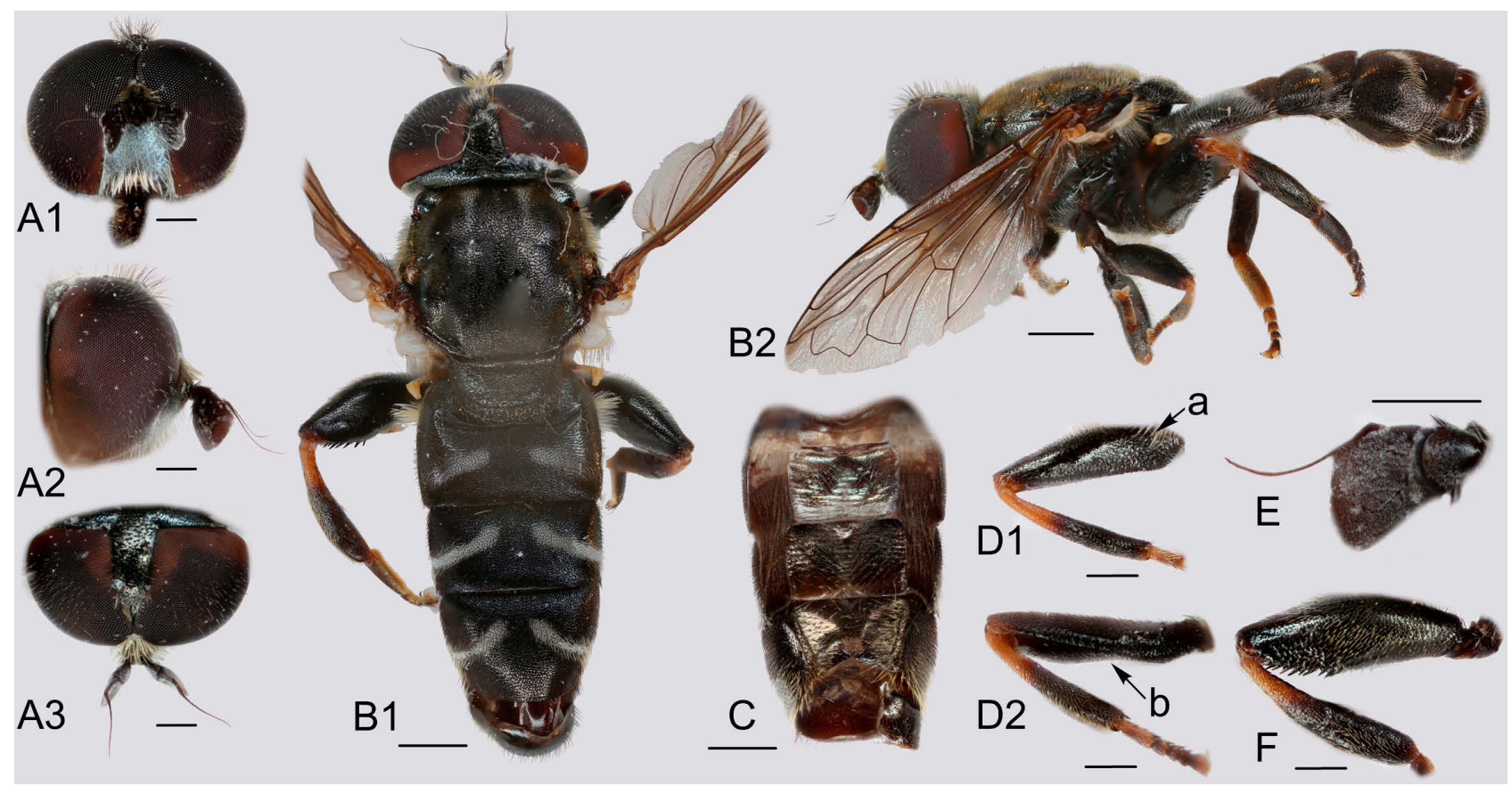

Fig. 2. Eumerus arctus van Steenis, sp. n., male. A - head: A1 - anterior view; $A 2$ - lateral view; $A 3$ - dorsal view; B - habitus: B1 - dorsal view; B2 - lateral view; C - sterna; D - mesoleg: D1 - anterior view; D2 - posteroventral view; E - antenna; $F$ - metaleg. a - pile on metasternum; $b$ - constriction of mesofemur. Scale bars: B, C: $1 \mathrm{~mm} ; \mathrm{A}, \mathrm{D}-\mathrm{F}: 0.5 \mathrm{~mm}$.

2017) (Fig. 1). There is also one female specimen from the northern part of Serbia probably belonging to E. tauricus Stackelberg, 1952 (Vujić \& Šimić, 1999) and one additional record of this species from Romania (Stănescu \& Pârvu, 2005). Since the identity of the specimens named E. tauricus is not clear and no DNA data are available for these specimens, it was not included in the list. We have included a newly discovered species from the Swiss Alps, E. arctus van Steenis, sp. n. in this paper as it is very similar to $E$. crispus Vujić \& Grković, sp. n.

\section{Eumerus arctus van Steenis, sp. $\mathbf{n}$.}

Figs 2, 3A

ZooBank taxon LSID:

040C56F5-24FB-4E8A-A2A8-AF60022B62DD

Diagnosis. Middle-sized species $(9 \mathrm{~mm})$ with overall blackish colour; black trapezoid shaped basoflagellomere (Fig. 2E); eyes white pilose with eye contiguity about 9 facets long; legs predominantly black, mesofemur curved and narrow in basal half (Fig. 2D2: b), body is covered with short pilosity. In having a black abdomen and the shape of the mesofemur E. arctus van Steenis, sp. n. is very similar to E. crispus Vujić \& Grković, sp. n., but differ in having a trapezoid basoflagellomere (Fig. 2E), which is rectangular in E. crispus Vujić \& Grković, sp. n., the shape of sternum IV (Fig. 2C) and the characters of the male genitalia in which $E$. arctus van Steenis, sp. n. has a more elongated and narrow posterior lobe on the surstylus (Fig. 3A1). The species is also similar to E. grandis from which it can be distinguished by black terga (Fig. 2B1), which are more or less reddish laterally in E. grandis (Fig. 9D), short pilose metafemur (Fig. 2F), which is long pilose in $E$. grandis, predominantly white pilose tergum VIII (pregenital segment) and especially the shape of the mesofemur (Figs 2D1, 2D2) in which E. grandis has an almost straight and evenly rounded mesofemur, while it is curved and constricted in E. arctus van Steenis, sp. n. Further, E. arctus van Steenis, sp. n. has a posterior surstyle lobe with distinct lateral wing-like protrusions (Fig. 3A1:w), which are absent in E. grandis (3B).

Description. Male. Head. Face, frons and postocular orbit blackish with slight bronze like sheen. Face covered in white pollinosity and dense yellowish-white pile (Fig. 2A1). Pilosity on frons long, dense, yellowish (Fig. 2A2). Pilosity on vertex long, yellowish-white, mixed with black pile around the ocellar triangle. Ocelli arranged in an isosceles triangle, longer than wide (Fig. 2A3). Distance from posterior ocellus to upper corner of eye is shorter than the distance from posterior to anterior ocellus. Distance between the posterior ocellus and eye margin is half as long as the diameter of the ocellus. Eyes covered with distinct whitish pilosity. Eyes contiguity about 9 facets long. Facets near the eye contiguity larger than those in the posterior part of the eye. Scape and pedicel black. Pilosity on pedicel short whitish, mixed with long black setae. Basoflagellomere trapezoid, black with gentle whitish grey pollinosity, striated, with ellipsoidal fossette (Fig. 2E). Arista black. Thorax. Scutum, scutellum and pleuron black, roughly punctuated, covered with dense short mixed black and yellowish-white pile, longer on pleurae. Scutum with two longitudinal and narrow vittae with grey pollinosity extending $2 / 3$ along the length of scutum, and short medium narrow vitta. Legs black with basal $1 / 3$ of tibiae yellow. Mesofemur dorsally curved and narrow in basal half (Fig. 2D2). Metafemur rather strongly thickened, apically with a row of 8-9 spinae on anterior ridge and a row 

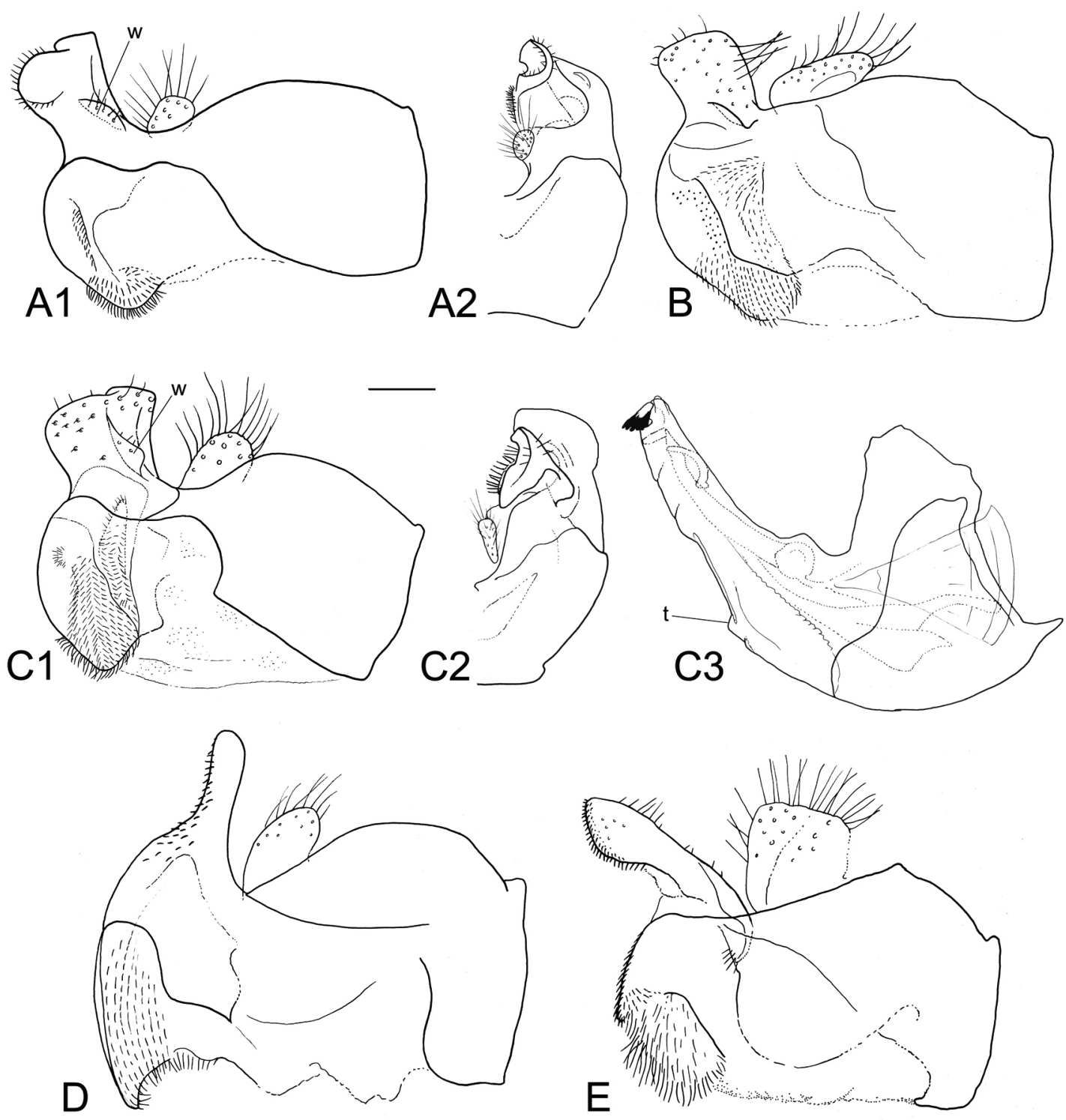

Fig. 3. Male terminalia. A - Eumerus arctus van Steenis, sp. n., epandrium: A1 - lateral view; A2 - dorsal view; $\mathrm{B}$ - Eumerus grandis, epandrium, lateral view. C - Eumerus crispus Vujić et Grković, sp. n.: C1 - epandrium, lateral view; C2 - epandrium, dorsal view; C3 - hypandrium, lateral view. D - Eumerus aurofinis, epandrium, lateral view. E - Eumerus richteri, epandrium, lateral view. w - lateral protrusion on posterior lobe on epandrium; $\mathrm{t}$ - double triangular expansion on the base of hypandrium. Scale bar: $0.2 \mathrm{~mm}$.

of 7-8 spinae on the posterior ridge. Ventral side of metafemur short pilose (Fig. 2F). Basitarsus of metatarsus longer than all of the other segments of the tarsus combined. Wing brownish, microtrichose, veins black. Postalar area with a row of black setae. Halter yellowish with whitish pedicel. Calypter whitish-yellow. Abdomen. Terga black, roughly punctuated (Fig. 2B1). Abdomen with very short mixed white and black pile, longer only on antero-lateral parts of tergum II. Three pairs of white pollinose fasciae are present on terga II-IV (Fig. 2B1). Sterna blackish with long whitish pilosity (Fig. 2C). Posterior margin of sternum IV rather straight. Genitalia. Base of hypandrium with small double triangular expansion (as in Fig. 3C3: t). Posterior surstyle lobe on epandrium simple, with a lateral winged extension (Fig. 3A1: w) and strong setae posteriorly (Fig. 3A1). Interior accessory lobe on posterior surstyle lobe covered with dense setulae.
Female unknown.

Type material. Holotype $\curvearrowright$, Switzerland: "Schweiz Graubünden, 0-3 km NW Bergün, 1200-1600 m, 18.vi.1993, leg. Lucas J.A.W." (NBC).

Type locality. Bergün (Switzerland).

Etymology. The name is derived from the Latin adjective arctus meaning compressed, referring to the constricted and curved mesofemur.

Distribution. This species is extremely rare, only known from its type locality in south-east Switzerland.

Biology. Larval stages undescribed. Flight period: June.

\section{Eumerus armatus Ricarte \& Rotheray in Ricarte et al., 2012}

Figs 4E2, 5A

Ricarte et al., 2012: 7. 


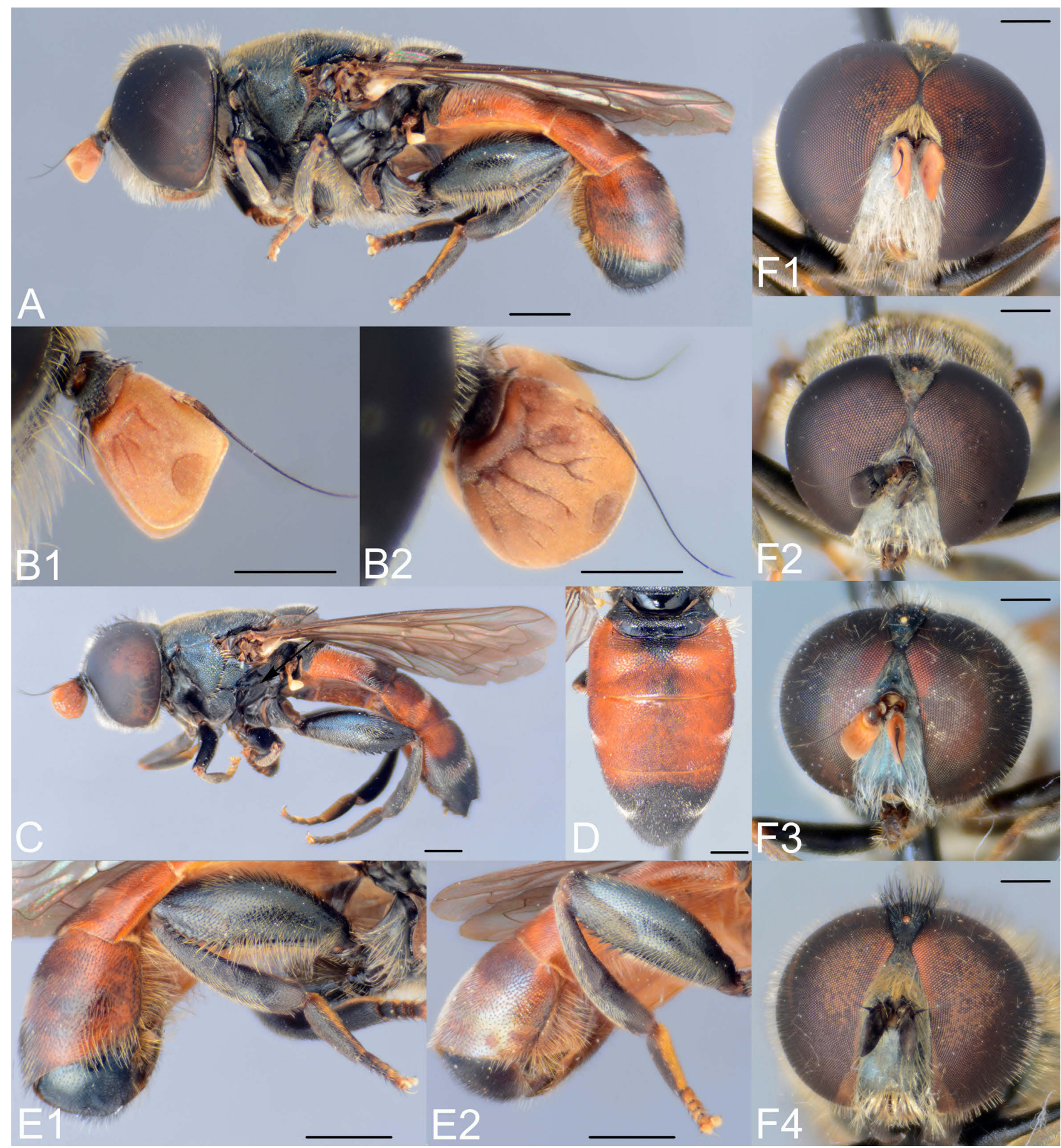

Fig. 4. A-D, E1 - Eumerus nigrorufus Grković et Vujić, sp. n. A - habitus, male, lateral view; B - antenna: B1 - male; B2 - female; C habitus, female, lateral view; D - terga, female; E1 - metaleg, apex of abdomen, male. E2 - Eumerus armatus, metaleg, apex of abdomen. F - head, male, anterior view: F1 - Eumerus nigrorufus Grković et Vujić, sp. n.; F2 - Eumerus tarsalis; F3 - Eumerus richteri; F4 - Eumerus sinuatus. Scale bars: A-E: $1 \mathrm{~mm}$; F: $0.5 \mathrm{~mm}$.

Diagnosis. Middle-sized species (8-9 $\mathrm{mm}$ ) with reddish appearance, mostly red abdomen and yellow basoflagellomere (as in Fig. 4B). This species is closely related and similar to a newly described species from Montenegro, $E$. nigrorufus Grković \& Vujić, sp. n. Body is covered in white to yellow mostly short pilosity, eyes nearly bare (as in Fig. 4F1). The basal part of male's hypandrium with serrated protuberance (Fig. 5A1). It can be distinguished from $E$. nigrorufus Grković \& Vujić, sp. n. by shorter body pilosity and pilosity on metafemur, which in E. nigrorufus Grković \& Vujić, sp. n. is denser and longer (Fig. 4E) and by distinct differences in the posterior lobe on male epandrium, which is slightly concave apically and with shorter and not so dense pilosity ventrally and dorsally in E. armatus (Fig. 5A2) and in E. nigrorufus Grković \& Vujić, sp. n., is oval apically and with denser and longer pilosity ventrally and dorsally (Fig. 5B1). Females of E. nigrorufus Grković \& Vujić, sp. n. and E. armatus are practically morphological- 

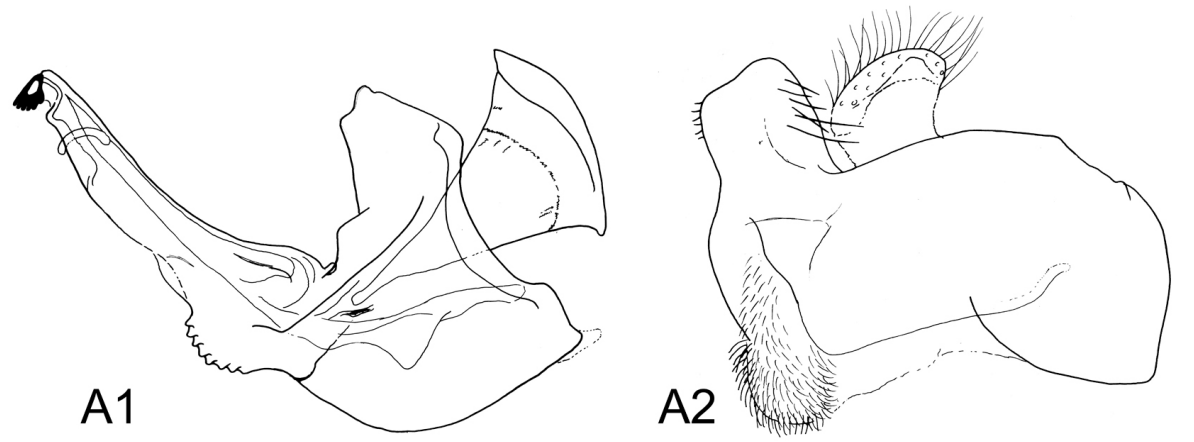

A3
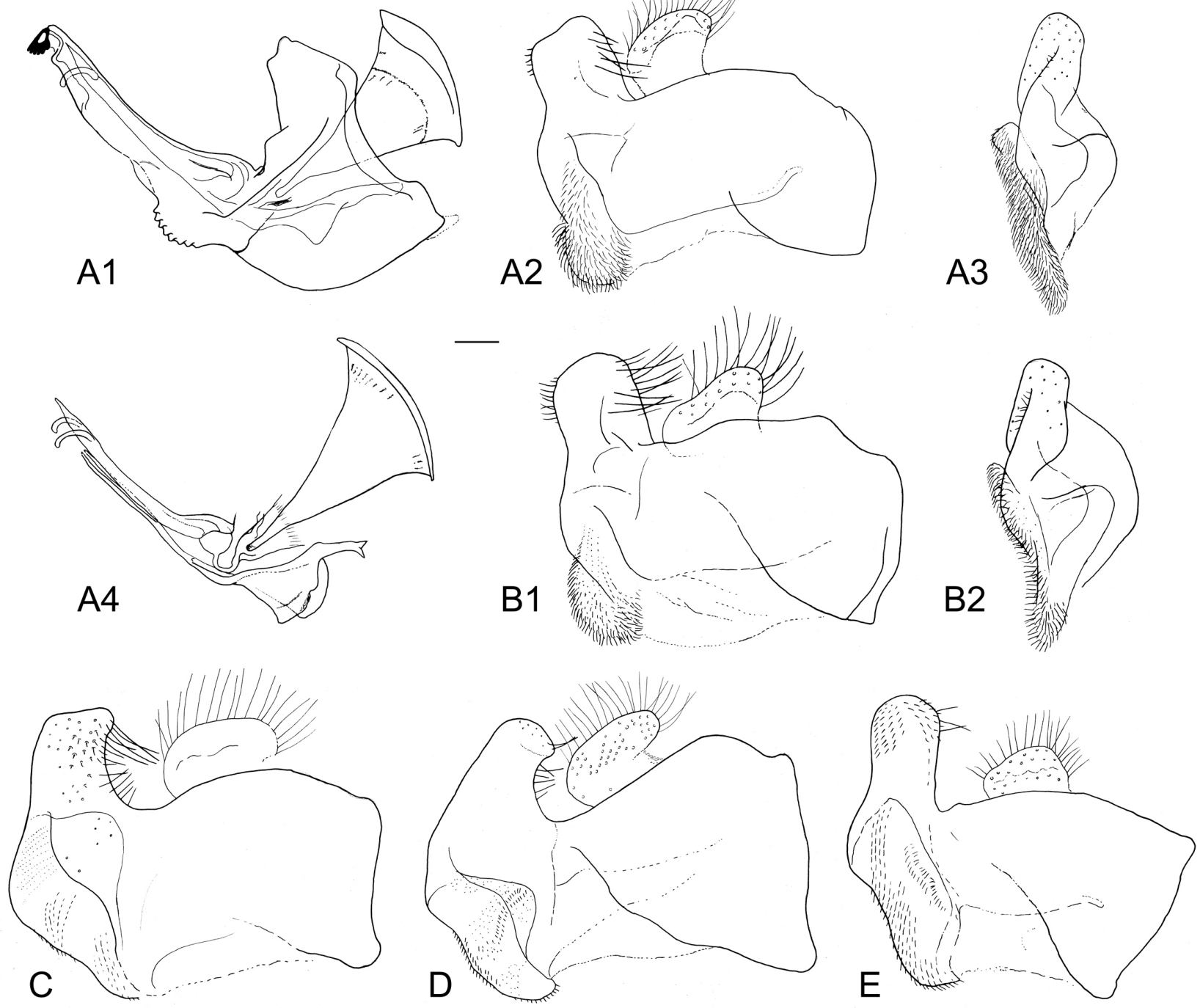

Fig. 5. Male terminalia. A - Eumerus armatus: A1 - hypandrium, lateral view; A2 - epandrium, lateral view; A3 - epandrium, anterior view; A4 - aedeagus and accessory structures. B - Eumerus nigrorufus Grković et Vujić, sp. n.: B1 - epandrium, lateral view; B2 - epandrium, anterior view. C-E - epandrium, lateral view: C - Eumerus rubrum; D - Eumerus tarsalis; E - Eumerus tricolor. Scale bar: $0.2 \mathrm{~mm}$.

ly indistinguishable (Fig. 4C), hence females of E. armatus can be recognized based on the description of females belonging to E. nigrorufus Grković \& Vujić, sp. n. Due to morphological similarity, distribution is a good indicator of what species a specimen belongs to.

Type material examined. Holotype $\delta^{\lambda}$ : Greece: Lesvos: Akrasi, 7.vi.2010, leg. Rotheray G. (NMS).

Other material examined. Cyprus: Kyrenia, $1 \hat{\delta}$, Laphithos, 30.vii.-13.viii.2017, leg. Özden Ö. (AE). Greece: Lesvos: $1 \hat{\jmath}$, 1ㅇ, Neochori, 2.v.2016, 1ठ, 3.v.2016, leg. Vujić A., Ačanski J., $1 \delta$, near Vafeios, 1.v.2016, leg. Vujić A., Ačanski. J.; 1 , Mantamados, 17-23.v.2001, leg. Vujić, A., 2ð, Ag. Ermogenis beach, 2.v.2008, leg. Vujić A.; Rhodes: 7ð̄, Kalathos, 29.v.2014, leg. Vujić A.; Samos: 1ठ, Marathokambos, 7.vi.2012, leg. Vujić A., Likov L., 2ð̂, 1ㅇ, Pyrgos, 21.iv.1988, leg. Lucas J.A.W., $1 \hat{\jmath}$, Pyrgos - entrance to the gorge, 8.vi.2012, leg. Vujić A., Likov L., 1ð̄, 1ㅇ, near Platanos, 9.vi.2010, leg. Rojo S., Vujić A., Ståhls G., $1 \overbrace{}^{\lambda}$, near Vourliotes, 7.vi.2010, leg. Rojo S., Vujić A., Ståhls G., 1ð̂, 1q, 2 km before Pytagora cave, 6.vi.2012, leg. Vujić A., Likov, L. (FSUNS).
Type locality. Lesvos (Greece).

Distribution. This species is endemic to the Eastern Aegean islands (Lesvos, Samos), Cyprus and Southwest Turkey (Fig. 1A).

Biology. Species prefers rocky and poorly vegetated ground (Ricarte et al., 2012). Larval stages undescribed. Flight period: April-August.

\section{Eumerus aurofinis Grković, Vujić \& Radenković in Grković et al., 2015}

Figs 3D, 6D, 7B, 8C

Grković et al., 2015: 364.

Diagnosis. Large species $(8-11 \mathrm{~mm})$ with black terga and very short body pilosity (Fig. 6D3). Eyes very slightly spaced in male (Fig. 6D2). Antenna reddish, oval (Fig. 6D4-5). Frons with distinctively white to yellow dense pilosity (Fig. 6D2). Anterior row of ventral spinae situated on the raised edge of the strong metafemur (Fig. 7B, 8C). 


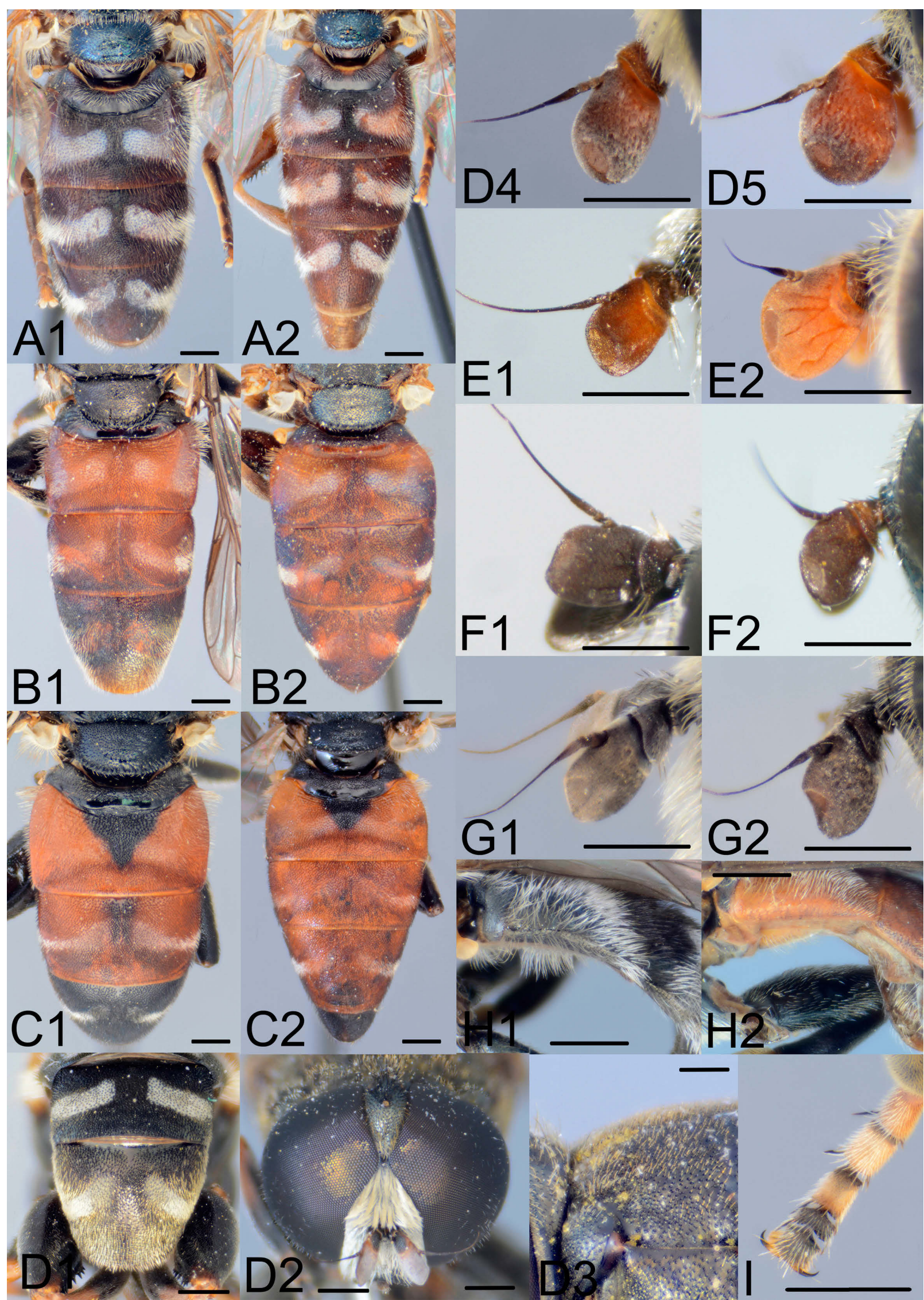

Fig. 6. A-C - terga. A - Eumerus richteri: A1 - male; A2 - female. B - Eumerus tarsalis: B1 - male; B2 - female. C - Eumerus tricolor: C1 - male; C2 - female. D - Eumerus aurofinis: D1 - terga III-IV, male; D2 - head, male, anterior view; D3 - pilosity on mesonotum, male, lateral view; D4 - antenna, male; D5 - antenna, female. E - Eumerus richteri, antenna: E1 - male; E2 - female. F - Eumerus tarsalis, antenna: F1 - male; F2 - female. G - Eumerus tricolor, antenna: G1 - male; G2 - female. H - pilosity on sterna: H1 - Eumerus richteri; $\mathrm{H} 2$ - Eumerus tricolor. I - Eumerus tarsalis, male, protarsus. Scale bars: A-C, H: $1 \mathrm{~mm}$; D-G, I: $0.5 \mathrm{~mm}$. 


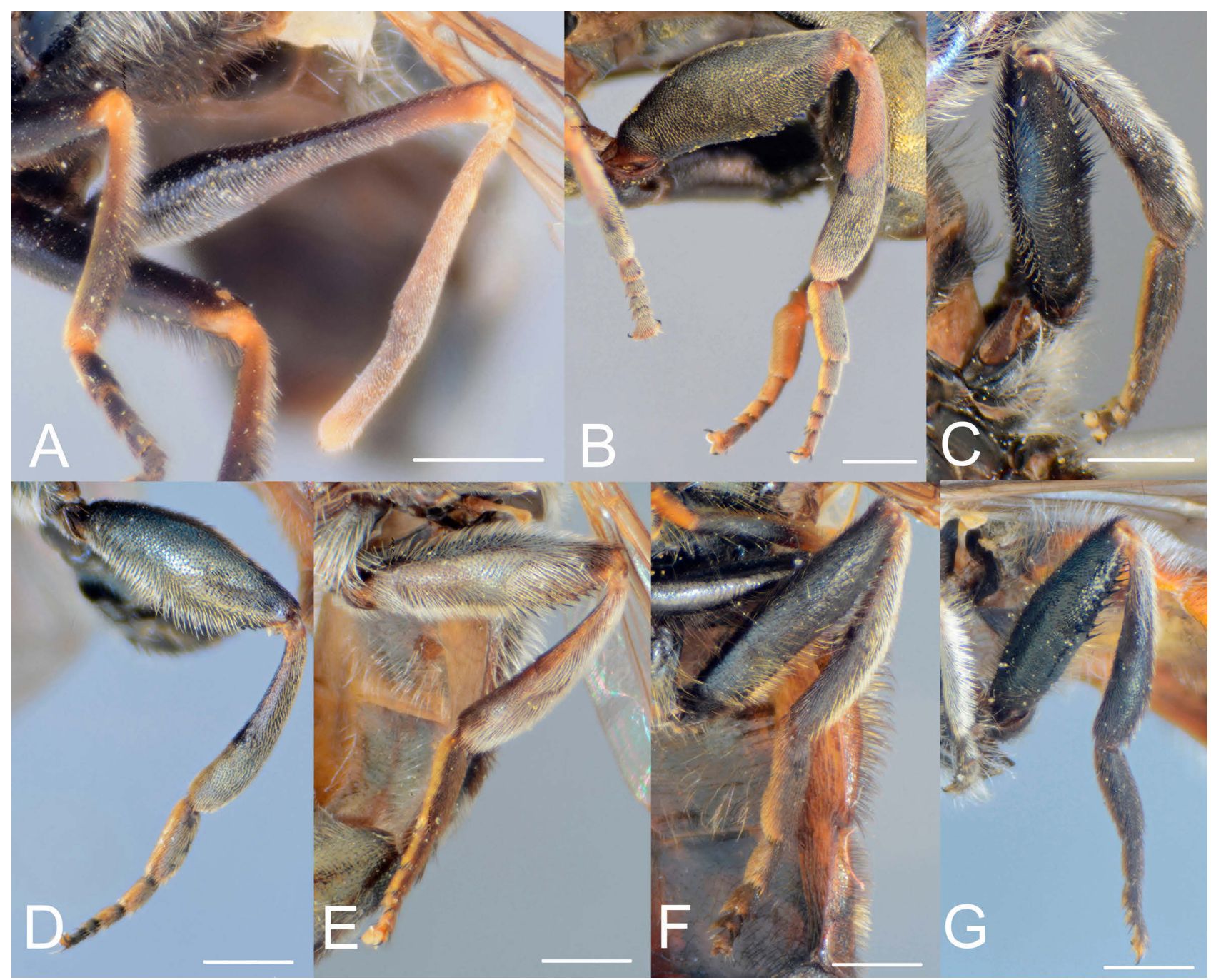

Fig. 7. Metaleg, male. A - Eumerus tenuitarsis; B - Eumerus aurofinis; C - Eumerus niveitibia; D - Eumerus tarsalis; E - Eumerus richteri; $\mathrm{F}$ - Eumerus sinuatus; $\mathrm{G}-$ Eumerus ovatus. Scale bars: $1 \mathrm{~mm}$.

Tergum IV posteriorly covered in characteristic yellow short pilosity with a golden reflection (Fig. 6D1). Posterior surstyle lobe on male epandrium elongated (Fig. 3D).

Type material examined. Holotype $\delta$ : Greece: Samos: Koumaradhei, 06.vi.2012, leg. Vujić A., Likov L. (FSUNS). Paratypes: Greece: Samos: $1{ }^{\lambda}, 1$,, Kosmadei, 10.vi.2010, leg. Rojo S., Vujić A., Ståhls G. (FSUNS).

Other material examined. Turkey: Mengenai Dagi, 1 우, N of Baskale, 2700-3000 m, 27-28.vi.1986, leg. Hurkmans, W. (NBC).

Type locality. Samos (Greece).

Distribution. Species is rare in Southeast Europe. It is endemic to eastern Aegean islands Lesvos, Samos and Rhodes (Greece) and to Muğla and Bozdağ mountains in southwest Turkey (Fig. 1B).

Biology. Species prefers clearings in forests, but has also been found near the edges of vineyards. Larval stages undescribed. Flight period: March-June.

\section{Eumerus crispus Vujić \& Grković, sp. n.}

Figs 3C, 9A-C, 10A-E

ZooBank taxon LSID:

CAAD7CCB-307B-4E6A-8A37-3AFAC98CB7F5
Diagnosis. Middle-sized species $(8-9 \mathrm{~mm})$ with blackish appearance (Fig. 9A), black abdomen in male, dark basoflagellomere (Fig. 9B), eyes covered with distinct whitish pile (Fig. 9C), contiguity of eyes about 8-10 facets long, legs mostly black, basal half of mesofemur twisted and narrow (Fig.10A: a), body covered with short pilosity (Fig. 10D). In having a black abdomen and the shape of the mesofemur E. crispus Vujić \& Grković, sp. n. is very similar to E. arctus van Steenis, sp. n., but differs in having a rectangular basoflagellomere (Fig. 9B1), which is trapezoid in E. arctus van Steenis, sp. n., the shape of sternum IV (Fig. 10E) and the characters of the male genitalia in which E. crispus Vujić \& Grković, sp. n. has a shorter and wider posterior lobe on the surstylus (Fig. 3C1, C2). This species is also similar to E. grandis from which it can be distinguished by black terga in male and very sparse and short ventral pilosity on metafemur (Fig. 10B-C), tergum II in female with reddish lateral markings (Fig. 9A3), while in E. grandis lateral sides of terga II-III (and tergum IV in female) are reddish. Further, E. crispus Vujić \& Grković, sp. n. has a posterior surstyle lobe with a distinct lateral wing-like protrusion (Fig. 3C1: w), which is absent in $E$. grandis (Fig. 3B). 


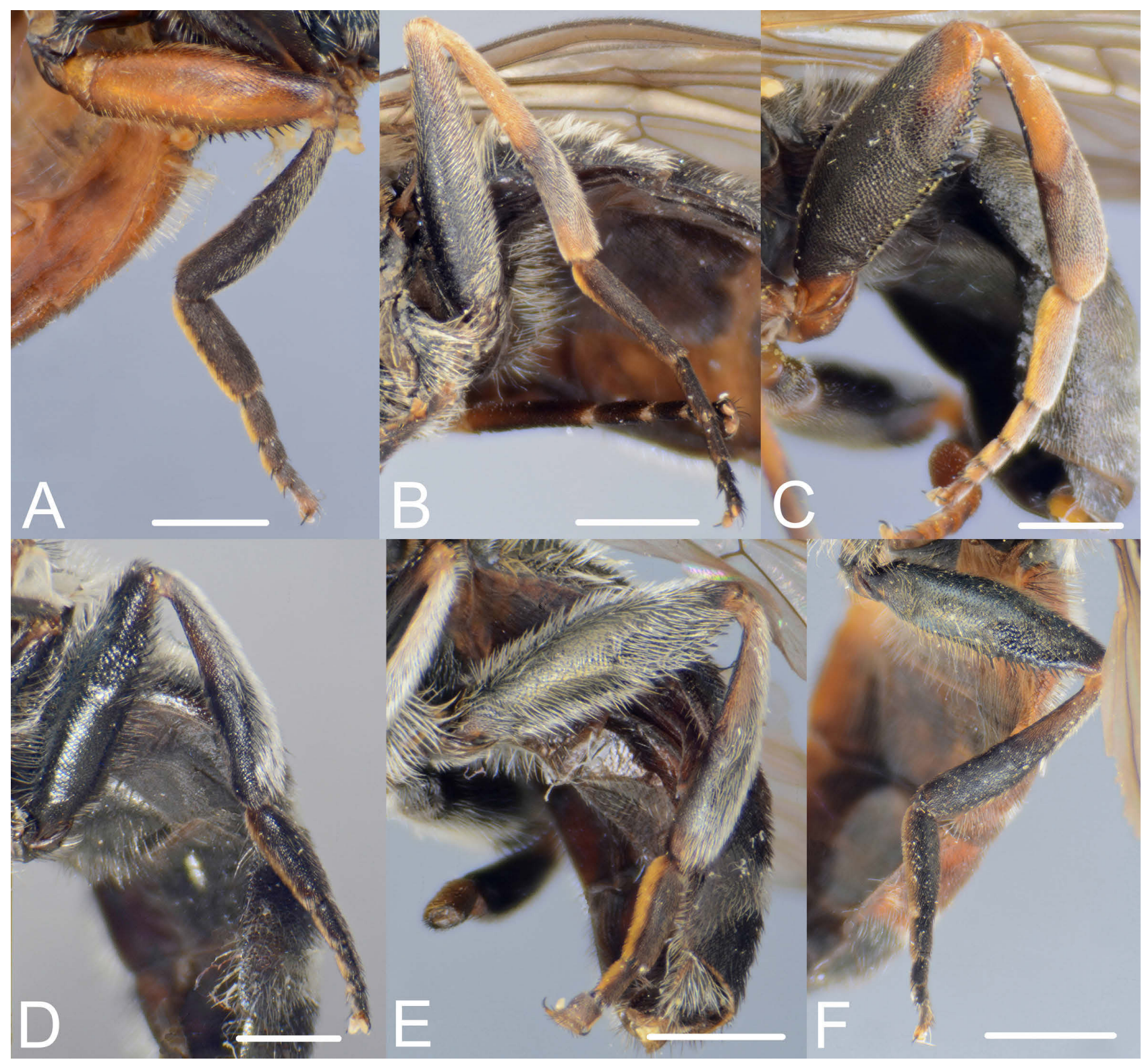

Fig. 8. Metaleg, female. A - Eumerus rubrum; B - Eumerus tenuitarsis; C - Eumerus aurofinis; D - Eumerus niveitibia; E - Eumerus richteri; $\mathrm{F}$ - Eumerus ovatus. Scale bars: $1 \mathrm{~mm}$.

Description. Male. Head. Face, frons and postocular orbit black to bronze. Face covered in white pollinosity and dense whitish pilosity. Pilosity on frons long, dense, grey yellow. Pilosity on vertex long, grey yellow, mixed with black pile around the ocellar triangle. In front of anterior ocellus there is a fringe of yellow pile directed downwards. Ocelli arranged in an isosceles triangle, longer than wide. Distance from posterior ocellus to upper corner of eye is shorter than the distance from posterior to anterior ocellus. Distance between the posterior ocellus and eye margin is smaller than the diameter of an ocellus. Eyes covered with distinct whitish pilosity (Fig. 9C). Contiguity of eyes about $8-10$ facets long. Facets near the eye contiguity remarkably larger than those in the posterior part of the eye. Scape and pedicel black. Pilosity on pedicel short whitish, mixed with long black setae. Basoflagellomere rectangular, dark brown to black with gentle whitish grey pollinosity, striated, with ellipsoidal fossette (Fig. 9B1). Arista black.
Thorax. Scutum, scutellum and pleuron black, roughly punctuated, covered with dense short yellow pile, longer on pleurae. Scutum with two longitudinal narrow vittae of grey pollinosity extending from $1 / 2$ to $2 / 3$ along the length of scutum, and short medium narrow vitta. Legs black with basal 1/2 of tibiae yellowish. Mesofemur with baso-dorsal bulge, twisted and narrow in basal half (Fig. 10A: a). Metafemur strongly thickened (Fig. 10B). Apically with a row of 8-9 spinae on anterior ridge and a row of 7-8 spinae on posterior ridge. Ventral pilosity on metafemur very short (Fig. 10B). Basitarsus of metaleg longer than all the rest of the segments of tarsus combined. Wing brownish, microtrichose, veins black. Postalar with a row of black setae. Halter yellowish with whitish pedicel. Calypter whitish-yellow. Abdomen. Terga black, roughly punctuated. Abdomen with very short yellow to black pilosity, longer only on antero-lateral parts of tergum II. Three pairs of white pollinose fasciae present on tegites II-IV (Fig. 


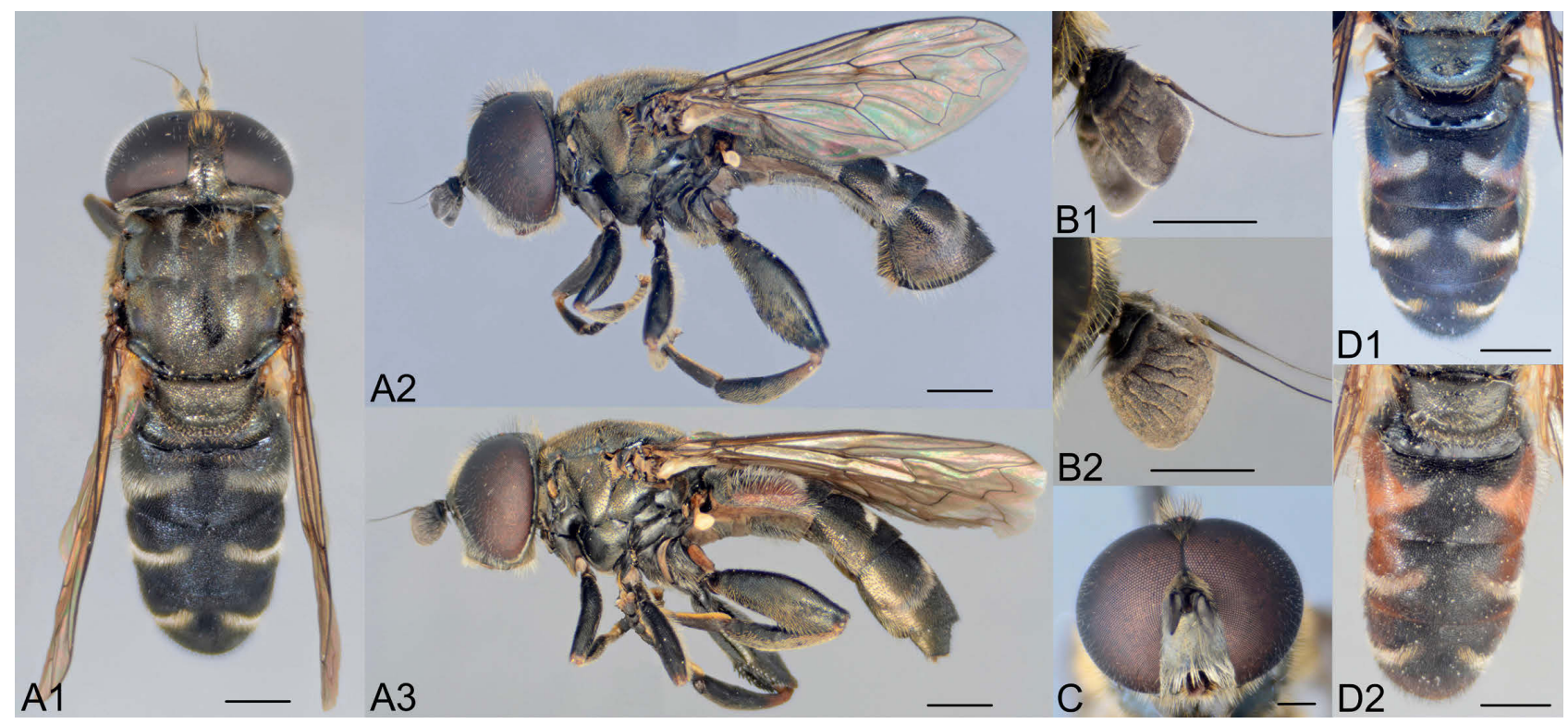

Fig. 9. A-C - Eumerus crispus Vujić et Grković, sp. n. A - habitus: A1 - male, dorsal view; A2 - male, lateral view; A3 - female, lateral view. B - antenna: B1 - male; B2 - female. C - head, male, anterior view. D - Eumerus grandis, male, terga. Scale bars: A, B, D: 1 mm; C: $0.5 \mathrm{~mm}$.

9A1). Sterna blackish with long whitish pilosity. Posterior margin of sternum IV concave (Fig. 10E). Genitalia. Base of hypandrium with small double triangular extensions (Fig. 3C3). Posterior surstyle lobe on epandrium with weak setae dorsally and a lateral winged extension (Fig. $3 \mathrm{C} 1$ ), which in dorsal view gives a three-limbed triangular appearance to the posterior lobe (Fig. 3C2). Interior accessory lobe of posterior surstyle lobe well developed, covered with dense setulae.

Female. Similar to male, except for normal sexual dimorphism. Head. Pile on face whitish, on frons greyish, not as dense as in male. Pile on frons about two times shorter than black ones on the vertical triangle. Ocelli in an isosceles triangle. Basoflagellomere enlarged, expanded ventrally, striated (Fig. 9B2). Thorax. Scutum with shorter longitudinal grey pollinose vittae. Medium vitta reduced. Scutum medially with short black pilosity. Legs black with sparse pilosity, mid femur less twisted. Abdomen. Terga black, except reddish lateral markings on tergum II (Fig. 9A3). Tergum IV usually predominantly black with a reddish anterior margin but sometimes red in the proximal half. Sterna black with very short and sparse white pilosity.

Type material. Holotype $\delta^{\lambda}$ : Serbia: Fruška Gora: Grabovo, 13.vii.2020, leg. Vujić A., Tot T. (FSUNS). Paratypes: $1 \hat{\jmath}, 1$, same data as holotype.

Type locality. Fruška Gora (Serbia).

Etymology. The name is derived from Latin adjective crispus meaning curled/curly, referring to the twisted mesofemur.

Distribution. This species is extremely rare in Southeast Europe, only known from its type locality in North Serbia (Fig. 1B).

Biology. Species is found in forest steppe and steppe areas on slopes along streams. Larval stages undescribed. Flight period: July.

\section{Eumerus grandis Meigen, 1822}

Figs 3B, 9D

Meigen, 1822: 203.

Diagnosis. Middle-sized species $(7-10 \mathrm{~mm})$ with short body pilosity. Basoflagellomere dark, in female enlarged with yellow patch basally. Terga predominantly black in male usually with small triangular reddish patches on terga II-III laterally (Fig. 9D2), which are sometimes almost absent (Fig. 9D1). Female with large red markings on terga. This species is similar to E. arctus van Steenis, sp. n. and E. crispus Vujić \& Grković, sp. n. described here, from which it differs by the colour of the terga, which are completely black in E. arctus van Steenis, sp. n. (Fig. 2B1) and E. crispus Vujić \& Grković, sp. n. (Fig. 9A1), mesofemur which is not narrow in basal half, as in the two mentioned species and longer ventral pilosity on metafemur. Posterior surstyle lobe on male epandrium is without a lateral wing-like protrusion (Fig. 3B) also characteristic for the two newly described species.

Type material. Species was described from Germany based on an unspecified number of males and females; in the Meigen collection deposited in MNHN, type material is missing. (https:// science.mnhn.fr/institution/mnhn/collection/ed/item/ed4095?list Index $=1 \&$ listCount $=3$ ); the identity of this species is confirmed by Doczkal D. (pers. comm.).

Other material examined. Austria: Graz, $1 \delta^{\Uparrow}$, leg. Gösting, B. 30 (CSCA). France: Dept Hautes Alpes, Vallouise: $1 \hat{\jmath} 1$ 우, Vallee de l'Onde, 13.vi.1992, leg. van Steenis W. \& van Steenis J. (SJ coll, WS), 1ð̄, 2q, 3.vi.2010, 1ð, 25.vii.2010, leg. van Steenis J. (JS); Hautes Alpes: $1 \delta$, leg. Brunissard, 23.vii.1998, leg. Niehuis, S. (CSCA); Hautes Alpes: 1ㅇ, leg. le Lombard, S. 8.vii.1997, leg. Niehuis M. \& O. Niehuis (CSCA); Isere, Villard de Lans: 10, col de 1'Arc, 20.vii.2010, leg. van Steenis J. (JS); Pyr. Or.: 1 $\sigma^{\uparrow}$, Gorge du Segre, vii.2007, leg. 'Pyr. excursie, Diertax Wageningen' (GP); Pyr. Or.: 1ठ̂, Gorges de la Caranca, 25.vi.1987, leg. 


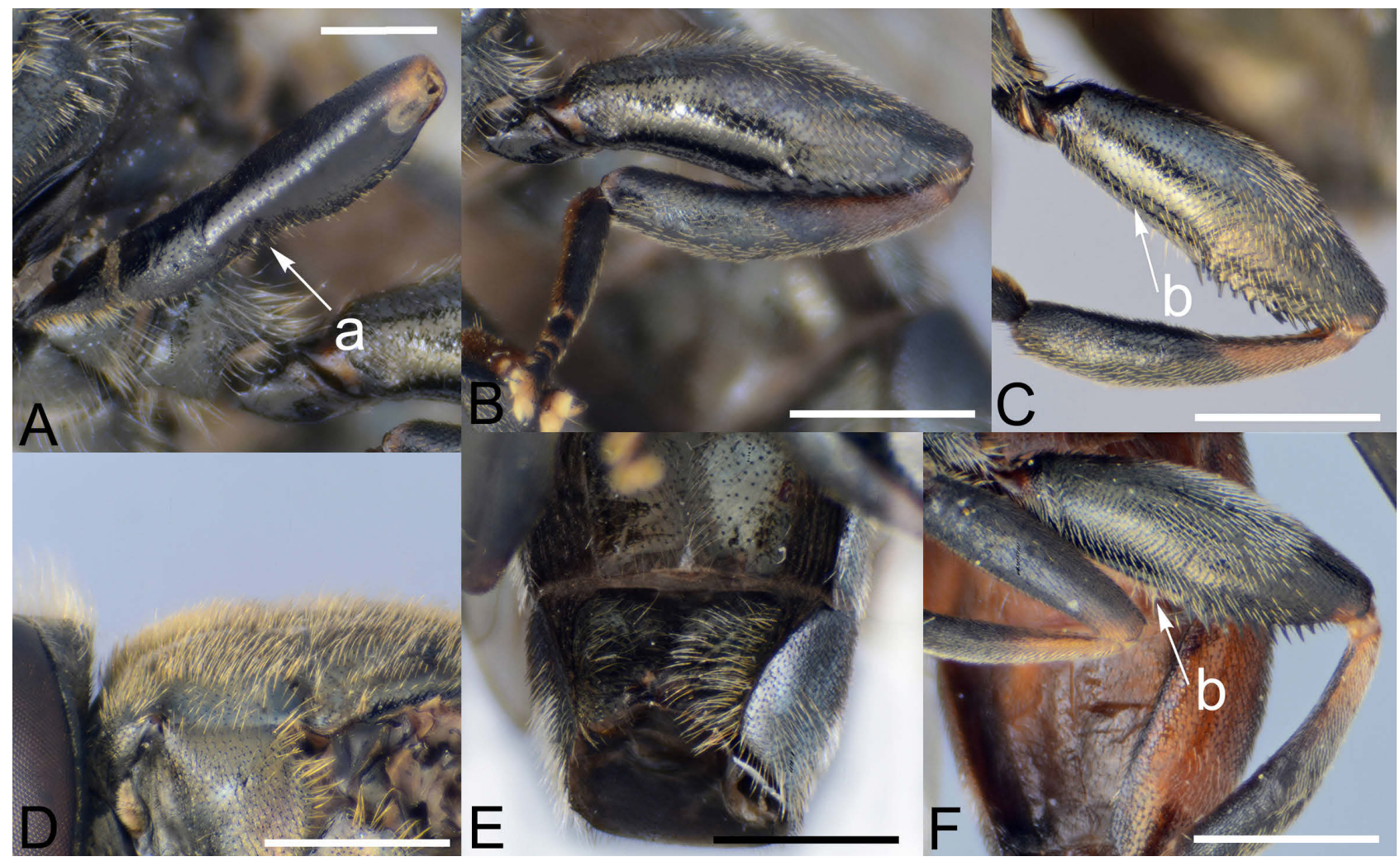

Fig. 10. A-E - Eumerus crispus Vujić et Grković, sp. n. A - mesoleg, male, anteroventral view; B - metaleg, male; C - metafemur and metatibia, female; D - pilosity on mesonotum, male, lateral view; $E$ - sternum IV, male. $F$ - Eumerus grandis, metafemur, female. a - constriction on mesofemur; $b$ - ventral pile on metafemur. Scale bars: A: $0.5 \mathrm{~mm}$; B-F: $1 \mathrm{~mm}$.

'Zomercursus', (GP); Pyrenees: 1§ึ, Vallee d'Eyne, 25.vii.2013, leg. Bot S. (SB); France Provence, Montagne d. Lure: 1 , Lauzon b. Cruis, 9.vii.1979, leg. Schacht, W. (NBC); France Savoie: 1̊̂, Valmeiner, 13.vii.1984, leg. Zwakhals C.J. (NBC); Col de la Machine: $1 \hat{\jmath}$, Vercors, 12.vii.1987, leg. Roess A. (NBC). Greece: Olymp: $3 \hat{\jmath}$, 10. viii.2013. leg. Devalez J.; 1へ̂, Barba, 18.-30. vi.2013., 1ठ, 13.-20.vii.2013., leg. Minachilis (MAegean); $1 \delta^{\lambda}$, Prionia, 18.vii.1998, leg. Vujić A. (FSUNS). Italy: Avise: 19, Aostadal, 11.vii.2004, leg. Slot J. (NBC); I-Valle d'Aosta 14 km S: 1 , , AO Lillaz 17, 27.vi.1996, leg. Schmid-Egger, C. (CSCA). Montenegro: Durmitor: 1ठ̄, Ćurevac, 23.vii.2014, leg. Vujić A.; 10̂, Pošćenje, 30.viii.2012, leg. Vujić A.; Plužine: 19, Vrbnica (Piva), 3.vii.2017, leg. Vujić A.; 1 \&, Stabansko jezero, 4.vii.2017, leg. Vujić A.; 1今̄, 2O, Mratinje, 5.vii.2017, leg. Vujić A. et al.; Orijen: $1 \hat{\jmath}$, Vratlo, 1.vi.2011, leg. Vujić A. Serbia: Prokletije: $2 \hat{\jmath}$, Krošnje, 28.vii.1994, leg. Radnović D.; Kopaonik: 1ðึ, Klisura Samokovske reke, 28.vii.1994, leg. Vujić A.; Đerdap: 2へ, Cigan-

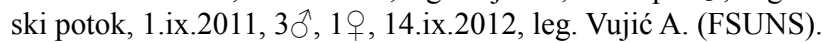

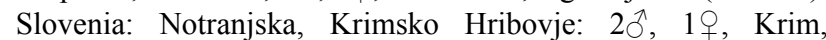
21.vi.2008, leg. van Steenis J. (SJ coll, WS). Spain: Gerona: 1 , Queralb, 6.viii.1985, leg. Wieringa J.J. (NBC). Sweden: Öland: 1, 3 km NW Vickleby, äng och lövskogsmark, 22.v.1993, leg. Danielsson R. (MZLU); Öl Högsmum: 19, Gheum, 17.vii.1932, leg. Gaunitz S. (MZLU).

Type locality. Germany.

Distribution. Species is known from southern Finland eastwards through central Europe (Poland, southern Germany, Switzerland, Austria, Italy), Slovenia (van Steenis et al., 2013), Bosnia and Herzegovina, Serbia, Montenegro, Romania and Greece, to the Transcaucasus (Armenia); also known supposedly from Mongolia and China; in France known from the Alps, the Cevennes and the Pyrenees; mountainous parts of northern Spain (Speight, 2020) (Fig. 1B).

Biology. This species can be found in dry Pinus forest, as well as in herbaceous plant rich open areas in coniferous and deciduous forests. Adults are recorded visiting Sedum album L. (Bartsch et al., 2009) and Peucedanum cervaria (L.) Cusson ex Lapeyr. (Ssymank \& Lair, 2014). The female is recorded ovipositing on the basal leaves of withered plants of Laserpitium latifolium L. (Sjöberg, 2015). Larval stages undescribed. Flight period: June-September.

Comments. Syrphus annulatus Fabricius, 1794 was recently recognized as synonym of Merodon natans (Vujić et al., 2021). In Peck (1988), in the list of synonyms of $E$. grandis it is stated that Syrphus annulatus Panzer, 1798 is a junior primary homonym of Syrphus annulatus Fabricius, 1794; however Panzer (1798) clearly stated "Syrphus annulatus Fabr", and thus annulatus is not a species epithet of Panzer. Syrphus annulatus Fabricius is Merodon natans and Syrphus annulatus sensu Panzer (Table 11, p. 547) is an Eumerus species later described by Meigen (1822) as $E$. grandis. In addition, we excluded $E$. varius Meigen, 1822 from the list of synonyms of $E$. grandis, since the syntype specimen marked as "1336/40", "Eumerus varius / Bhm." does not belong to this species, but to E. tricolor. We here designate this syntype specimen as a lectotype of E. varius Meigen, 1822 in order to stabilize the name. 


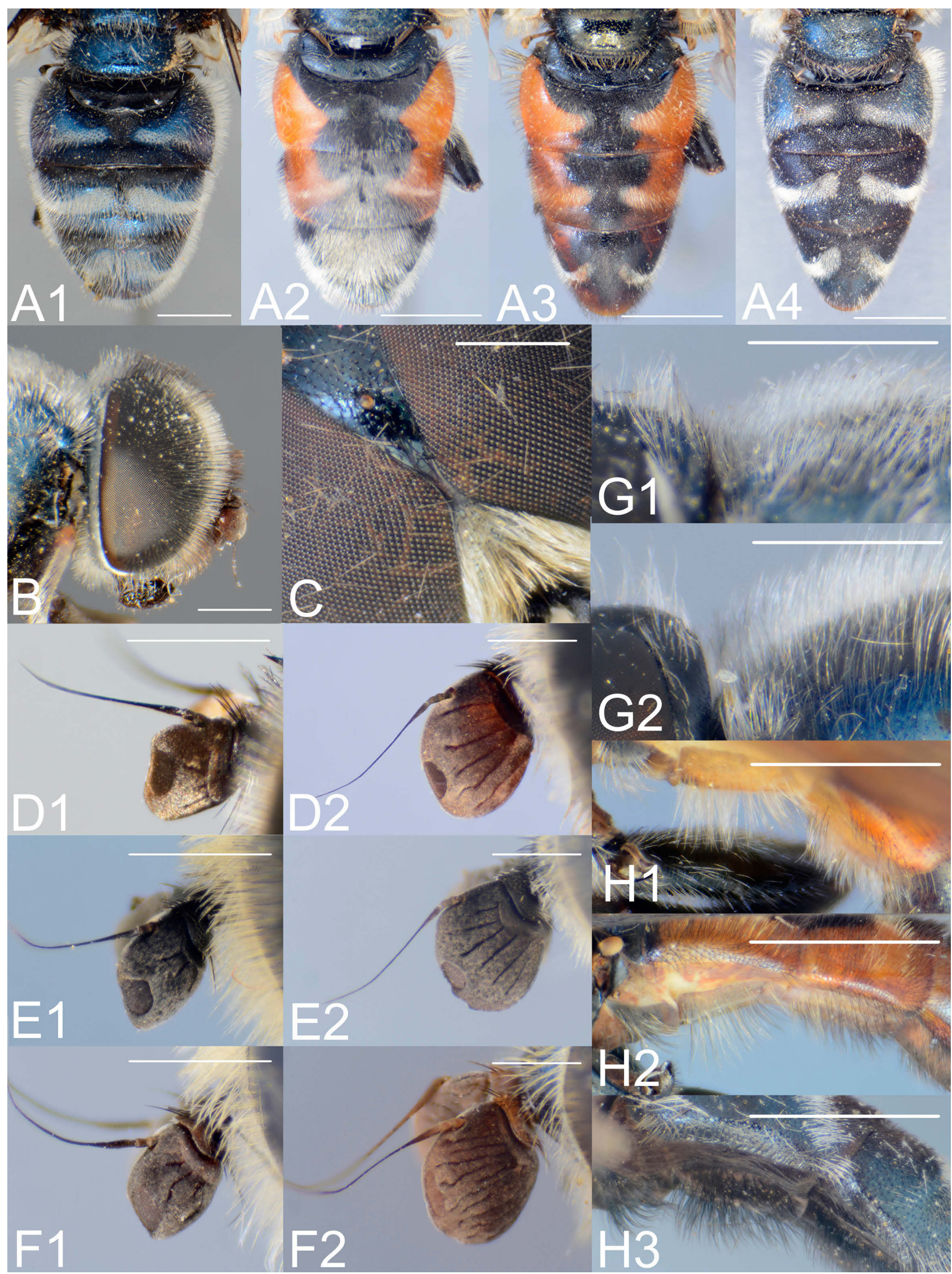

Fig. 11. A - terga, male: A1 - Eumerus niveitibia; A2 - Eumerus ovatus; A3 - Eumerus sinuatus; A4 - Eumerus tenuitarsis. B - Eumerus niveitibia, male, head, lateral view. C - Eumerus ovatus, male, contiguity of eyes. D-F - antenna. D - Eumerus niveitibia: D1 - male; D2 - female. E - Eumerus ovatus: E1 - male; E2 - female. F - Eumerus sinuatus: F1 - male; F2 - female. G - pilosity on mesonotum, male: $\mathrm{G} 1$ - Eumerus tenuitarsis; G2 - Eumerus ovatus. $\mathrm{H}$ - pilosity on terga, male: $\mathrm{H} 1$ - Eumerus ovatus; $\mathrm{H} 2$ - Eumerus sinuatus; $\mathrm{H} 3$ Eumerus tenuitarsis. Scale bars: A-B, D-H: $1 \mathrm{~mm}$; C: $0.5 \mathrm{~mm}$. 

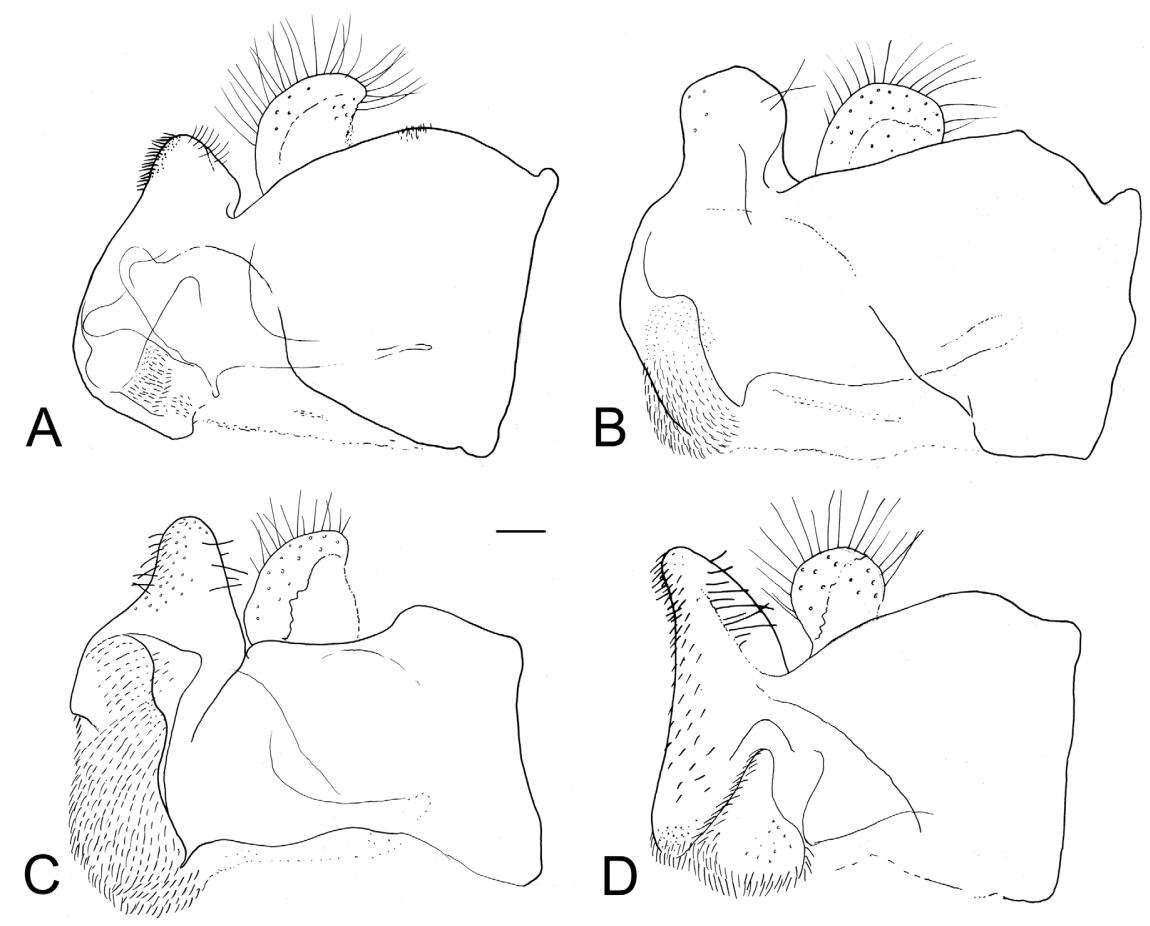

Fig. 12. Male terminalia. Epandrium, lateral view. A - Eumerus niveitibia; $\mathrm{B}$ - Eumerus ovatus; $\mathrm{C}$ - Eumerus sinuatus; D - Eumerus tenuitarsis. Scale bar: $0.2 \mathrm{~mm}$.

\section{Eumerus niveitibia Becker, 1921}

Figs $7 \mathrm{C}, 8 \mathrm{D}, 11 \mathrm{~A} 1, \mathrm{~B}, \mathrm{D}, 12 \mathrm{~A}$

Becker, 1921: 69 .

Redescribed in Ricarte et al., 2018: 265.

Diagnosis. Large species $(10-12 \mathrm{~mm})$ with blue reflections (Fig. 11A1). Eyes covered in long and dense white pilosity (Fig. 11B), in male holoptic, with about a ten facets long eye contiguity. Antenna brown (Fig. 11D1), enlarged in female (Fig. 11D2). Body pilosity predominantly long. Metatibia covered in characteristic silvery-white pilosity dorsally (Figs 7C, 8D). Male epandrium small, simple, with dense short pilosity ventrally on posterior lobe (Fig. 12A). Base of male's hypandrium with an elongate transversely striated lingula.

Type material examined. Neotype $\delta$ (designated by Ricarte et al., 2018): Bulgaria: Nessebar, 21.vii.2009, leg. Barendregt, A. (NBC).

Other material examined. Greece: Zakynthos: $1 \hat{\jmath}$, Mt. Vrachionas, 16.vii.2008, leg. Pennards G.W.A. (GP); Lakonia: 1ठ, Parori, 6.vi.1995, 1ㅇ, 17.v.1991, leg. den Hollander G. (NBC).

New type locality. Nessebar (Bulgaria).

Distribution. This species is very rare in Southeast Europe. It is found in Greece, Bulgaria; the Caucasus mountains and Egypt (Fig. 1C).

Biology. This species can be found in vegetation growing on naturally burnt ground, two years after forest fires. It is known to visit Ferulago sylvatica (Besser) Rchb. (Standfuss \& Claussen, 2007), and occurs in rocky quarries and herbaceous plant rich olive grove terracing (Ricarte et al., 2012). Larval stages undescribed. Flight period: MaySeptember.

\section{Eumerus nigrorufus Grković \& Vujić sp. $\mathbf{n}$.}

Figs 4A-D, E1, F1, 5B

ZooBank taxon LSID:

9B0C109A-0B56-40D2-BE67-EEA4FB0B3C0B

Diagnosis. Middle-sized species $(8-9 \mathrm{~mm})$ with reddish appearance and mostly red abdomen (Fig. 4A, C, D) and yellow basoflagellomere (Fig. 4B). This species is closely related to and very similar to E. armatus. Body is covered in yellow mostly short pilosity, eyes almost bare (Fig. 4F1). The basal part of male's hypandrium with serrated protuberance (as in Fig. 5A1). It can be distinguished from $E$. armatus by longer body pilosity and longer and denser ventral pilosity on metafemur (Fig. 4E1) and by distinct differences in the posterior lobe on the epandrium of males, which is oval apically and with longer and denser pilosity ventrally and dorsally in E. nigrorufus Grković \& Vujić, sp. n. (Fig. 5B1) compared to E. armatus in which it is slightly concave apically and with shorter and not so dense pilosity ventrally and dorsally (Fig. 5A2). Females of E. nigrorufus Grković \& Vujić, sp. n. and E. armatus are practically morphologically indistinguishable (Fig. 4C, D), therefore, distribution is an important factor in determining the species.

Description. Male. Head. Face, frons and postocular orbit black to bronze. Face covered in white pollinosity and dense white to yellow pilosity (Fig. 4F1). Pilosity on frons long, dense, yellow. Pilosity on vertex long, yellow, mixed with a few black piles behind the anterior ocellus. In front of anterior ocellus there is a fringe of downwardly directed yellow piles. Ocelli arranged in an isosceles triangle, longer than wide, located anteriorly on vertex. Distance from 


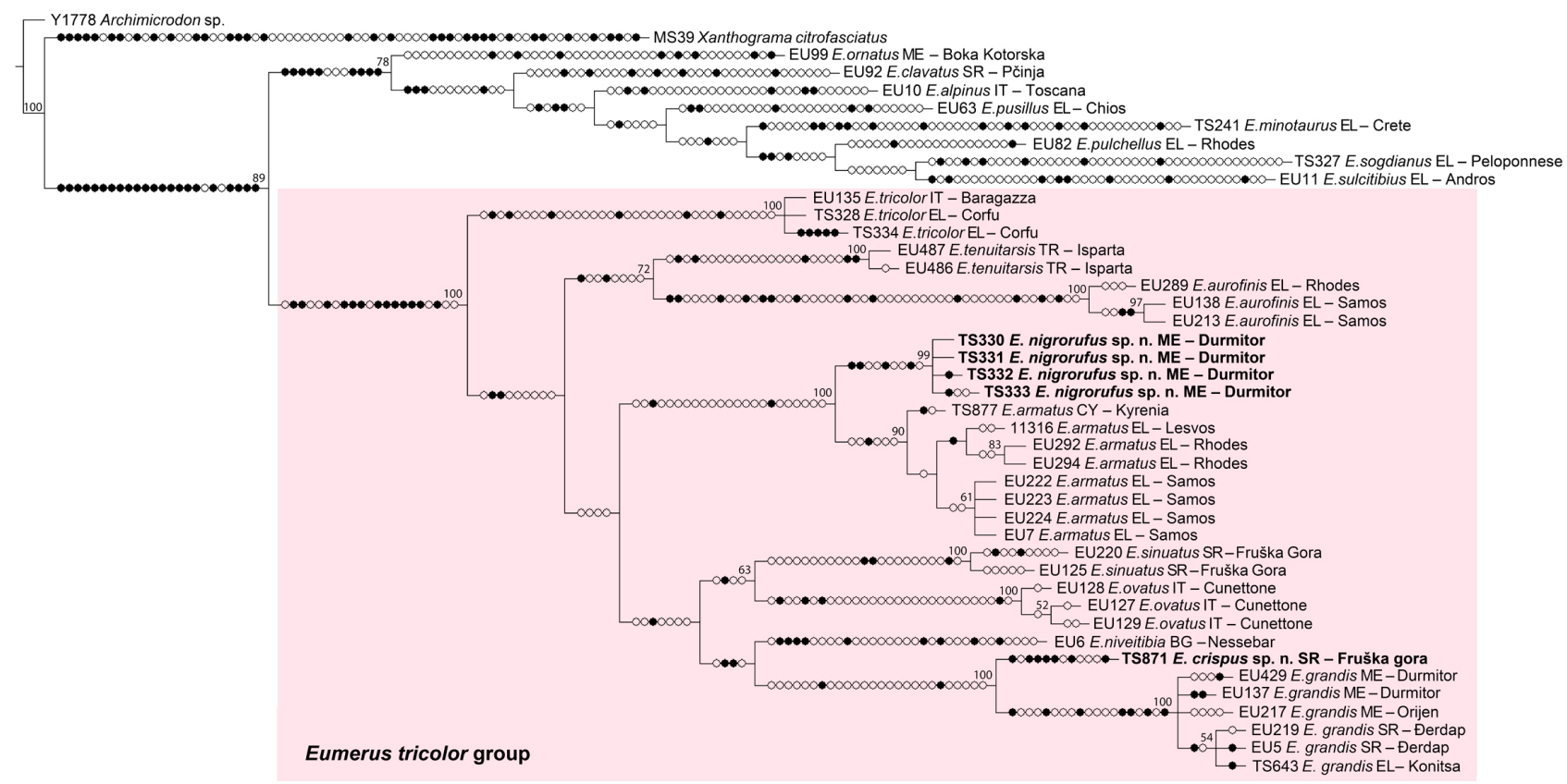

Fig. 13. Strict consensus tree of three parsimonious trees resulting from a parsimony analysis of the COI gene. Length of steps $=1219$, Consistency Index $=50$, Retention Index $=75$. Filled circles denote unique changes, open circles non-unique. Bootstrap support values $(\geq 50)$ are depicted near nodes.

posterior ocellus to upper corner of eye is longer than the distance from posterior to anterior ocellus. Distance between the posterior ocellus and eye margin is smaller than the diameter of an ocellus. Eyes nearly bare (Fig. 4F1). Contiguity of eyes about 5-6 facets long. Facets near the eye contiguity remarkably larger than those in the posterior part of the eye. Scape and pedicel dark to light brown. Pilosity on pedicel short yellow mixed with long black setae. Basoflagellomere slightly axe-shaped to rectangular, sometimes more elongated, yellow with gentle whitish pollinosity, striated, with flattened ellipsoidal fossette distally on outer side (Fig. 4B1). Arista dark with brighter basal segments. Thorax. Scutum, scutellum and pleuron black, roughly punctuated, covered with dense short yellow pile, longer on pleurae. Scutum with two wider longitudinal vittae of grey pollinosity and medium narrow vitta, all extending from $2 / 3$ to $3 / 4$ along the length of scutum. Scutellum with barely visible blue tinge. Ventral side of metafemur with two rows of dense pilosity, longer and slightly curly posteriorly. Legs black with yellow ventral side of tarsi. Mid femur postero-ventrally with a fringe of very dense yellow pilosity. Metafemur strongly thickened (Fig. 4E1). Apically with a row of 7-9 spinae on anterior ridge and a row of 4-6 spinae on the posterior ridge. Basitarsus of metaleg longer than the rest of the segments of tarsus combined. Wing mild brownish, microtrichose. Postalar with a row of black setae. Halter yellowish with darker pedicel. Calypter whitish-yellow. Abdomen. Tergum I black, terga II-III mostly red in some places with uneven blurred blackish patches. Tergum IV almost black with red anterior margin. Abdomen with very short yellow to black pilosity, longer only on antero-lateral parts of tergum II. Sternum I blackish, sterna II-III yellow, usually translucent. Sternum
IV yellow to brown. Pilosity on sterna long, yellow. Posterior margin of sternum IV V-shaped, sometimes elevated. Three pairs of white pollinose fasciae present on terga II-IV. Genitalia. Base of hypandrium with serrated double expansion (as in Fig. 5A1). Posterior surstyle lobe on epandrium simple, with strong setae posteriorly (Fig. 5B1). Interior accessory lobe on posterior surstyle lobe covered with dense setulae (Fig. 5B2).

Female. Similar to the male, except for normal sexual dimorphism. Head. Pile on face and frons whitish, not as dense as in male. Pile on frons about two times shorter than on vertical triangle. Eyes almost bare with a few short sparse piles ventrally. Ocelli in an almost equilateral triangle. Basoflagellomere blurred to reddish-yellow, very enlarged, expanded ventrally, striated (Fig. 4B2). Thorax. Scutum with longitudinal grey pollinose vittae. Medium vitta reduced to a triangular patch anteriorly. Legs black with scarcer pilosity than in male. Abdomen. Tergum I black, terga II-III mostly red with a mixture of blurred blackish patches. Tergum IV is usually predominantly black with a reddish anterior margin but sometimes red in the proximal half (Fig. 4D). Sterna reddish brown with very short and sparse white pilosity.

Type material. Holotype $\delta$ : Montenegro: Durmitor: Komarnica, Pošćenje, 31.vii.2016, leg. Vujić A., Vujić S. (FSUNS) Paratypes: Montenegro: Durmitor mountain: $2 \hat{\jmath}, 2$, , Komarnica, Pošćenje, 1.-4.vi.2016, leg. Vujić A., Likov L., Miličić M., Veličković N., 1, 9.vii.2016, leg. Grković A. (JS), 2ð̂, 1 , 30.vii.2016, $2 \widehat{\jmath}, 3$ ㅇ, 31.vii.2016, leg. Vujić A., Vujić S. (FSUNS, JS).

Type locality. Durmitor (Montenegro).

Etymology. The species name is derived from the remarkable red abdomen in contrast to black appearance in both the male and female. 
Distribution. This species is very rare in Southeast Europe and it is found only in Montenegro (Durmitor mountain) (Fig. 1A).

Biology. This species occurs in both mountain hay and wooded meadows. Larval stages undescribed. Flight period: June-July.

\section{Eumerus ovatus Loew, 1848}

Figs 7G, 8F, 11A2, C, E, G2, H1, 12B

Loew, 1848: 109.

Eumerus bicolor Rondani, 1857: 89 (synonymized by Peck, 1988: 160).

Diagnosis. Large species $(10-11 \mathrm{~mm})$ with long body pilosity (Fig. 11G2, H1). Eyes covered in long and dense white pilosity, in male, slightly dichoptic (Fig. 11C). Terga with triangular red markings laterally. Terga III-IV in male covered in characteristic, silvery-white velvet pilosity (Fig. 11A2), which is not present in the female. The female could be confused with the female of E. sinuatus, but is most easily distinguished by the sculpturing on the antenna, which is evenly striated with around six furrows in E. ovatus (Fig. 11E2), while in E. sinuatus there are many irregular and longer furrows (Fig. 11F2). In females of $E$. ovatus, the ocellar triangle is large, the distance between upper corner of eye and posterior ocellus is shorter than the distance between posterior and anterior ocelli.

Type material examined. Lectotype $\hat{\sigma}$ of Eumerus ovatus Loew, 1848 (designated here to stabilize the name): "Mitteleuropa": "4/6 67", "Coll./H. Loew", "Eumerus/ovatus/m.”, "Typus" [faded red label], "Zool. Mus./Berlin", "Lectotype §/Eumerus ovatus / Loew, 1848; design./J. \& W. van Steenis, 2016" [red label], "QR code http://coll.mfn-berlin.de/u/dbc6ee" (ZMHB). Loew (1848) did not state the number of syntypes, which is the reason why no paralectotypes were designated.

Type material of Eumerus bicolor Rondani, 1857 was not studied. In the description, Rondani (1857) clearly states the main diagnostic character is silvery-white pilosity on posterior terga. Based on description and synonymy published in Peck (1988) and Sforzi \& Sommaggio (2021) we accept the status of $E$. bicolor as a junior synonym of $E$. ovatus. Lectotype is designated by Sommaggio (2007).

Other material examined. France: $1 \delta^{\lambda}, 1$, Chartreuse, vii, (IRSNB). Germany: Frankfurt Oder: $1 \hat{\jmath}, 2+$, leg. Rieder, M.P. (IRSNB); Greece: 1ð̂, Konitsa, 7.vi.1995, 2へ, 4.-11.vi.1996, leg. Dils J. (JD). Croatia: $1 \hat{\jmath}$, Umag, $1 \hat{\jmath}$, Zagreb, unknown dates (NHMW). Italy: $3{ }^{\lambda}, 1$, near Cunettone, 6.vi.2013, leg. Vujić A. (FSUNS); 1 ภ̄, 2 ㅇ, Trento 250 m, Riva del Garda, 18.-31.v.1990, leg. Zwakhals, C.J. (NBC); 1ठ̃, Lago di Cavazzo, 23.-30.v.1950, leg. Demelt (CDFA). Serbia: Zlatibor: 2ో, 1 ㅇ Zlatibor 1, 9.v.2018, leg. Vujić A., Popov S.; Cer: 1ठ̃, Krstovi, 27.vii.2019, leg. Vujić A. (FSUNS) Slovenia: Notranjska, Krimsko Hribovje:

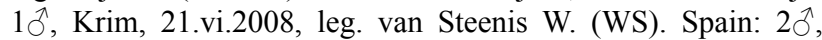
Campelles, 23.vi.2018, leg. Vujić A. (FSUNS).

Type locality. Central Europe.

Distribution. This species is rare in Southeast Europe. It is known from Lithuania and Poland, southern Germany, Czech Republic through central Europe (Switzerland, Austria) to Romania, Ukraine and the Caucasus mountains; in southern Europe from Spain through southern France and Italy to Balkan Peninsula (Speight, 2020) (Fig. 1D).

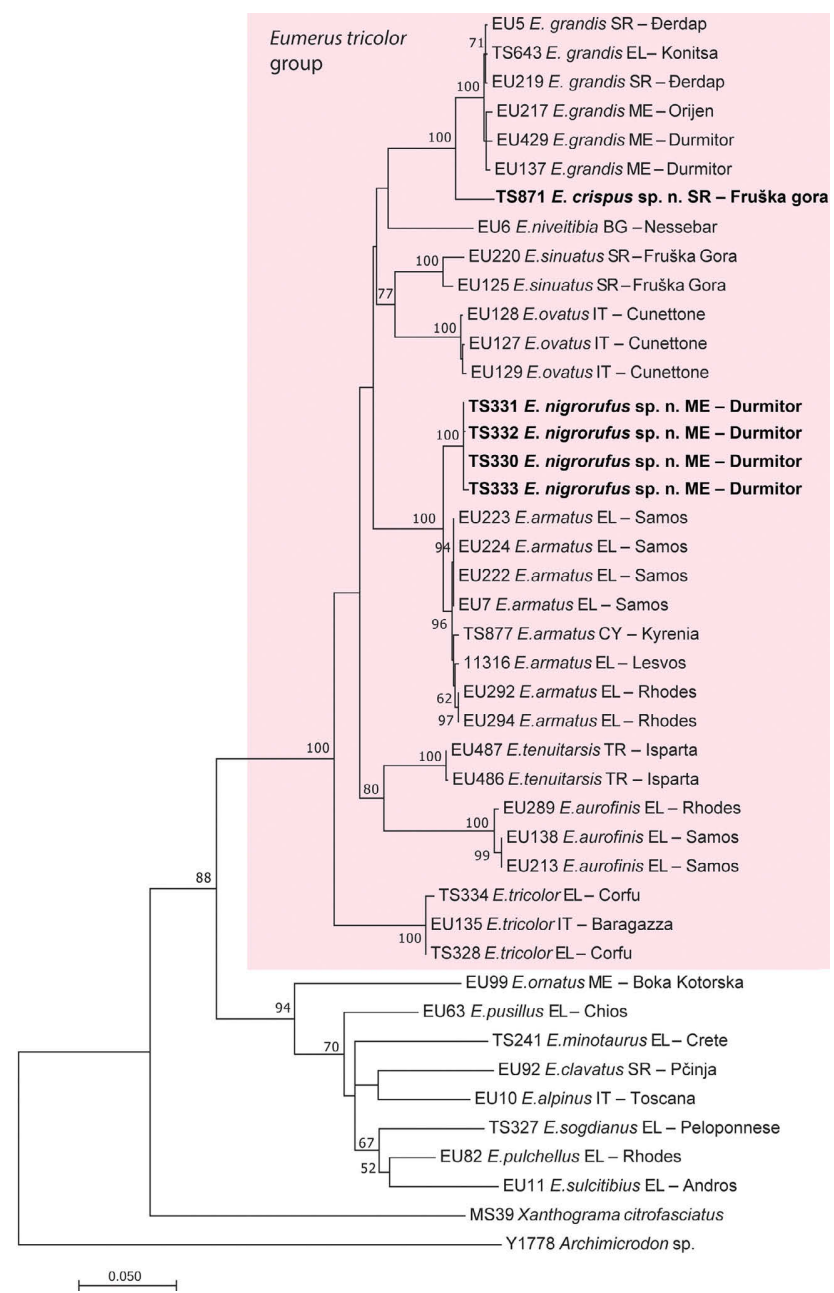

Fig. 14. Molecular phylogenetic analysis using the Maximum Likelihood method based on the General Time Reversible model conducted in MEGA version 7.0. A discrete Gamma distribution was used to model evolutionary rate differences among sites ( 5 categories $(+G$, parameter $=0.9392)$ ). The rate variation model allowed for some sites to be evolutionarily invariable $([+1], 49.67 \%$ sites $)$. Bootstrap support values $(\geq 50)$ are depicted near nodes.

Biology. This species can be found in open areas, fringes of thermophilous forest and herbaceous plant rich, dry and semi-arid, open, unimproved and calcareous grassland, scrub and garrigue (Speight, 2020). Larval stages undescribed. Flight period: May-September.

\section{Eumerus richteri Stackelberg, 1960}

Figs 3E, 6A, E, H1, 7E, 8E

Stackelberg, 1960: 446.

Diagnosis. Middle-sized species $(8-10 \mathrm{~mm})$, usually with bright appearance but without red markings on terga and with long white pilosity on eyes and mesonotum in male, while in female pilosity on mesonotum is short. Antenna oval, yellow (Fig. 6E1), enlarged in female (Fig. 6E2). Eyes dichoptic in male. Posterior margin of occiput medially with small pollinose spot. Terga II-IV with large white pollinose fasciae (Fig. 6A). Male epandrium elongated, wide apically and ventrally bent (Fig. 3E). 


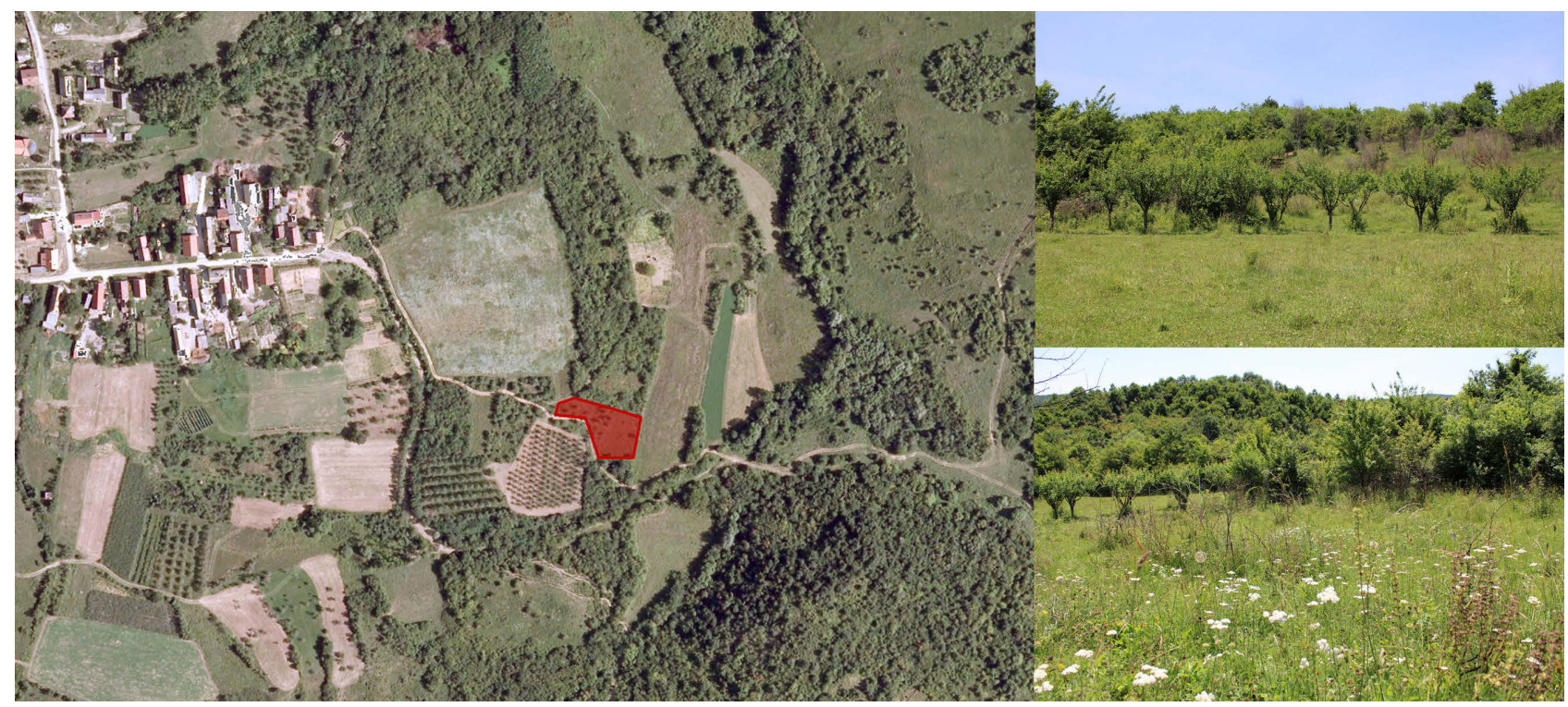

Fig. 15. Type locality of Eumerus crispus Vujić et Grković, sp. n., meadow near the village Grabovo on Fruška Gora Mountain (Serbia). Photo: Tamara Tot.

Type material examined. Holotype $\delta^{\top}$ : Azerbaijan: "C. Ләкәтаг Джульф./ p-на, Нахичев. АССР/ В. Рихтер 30.vi.959”, "Eumerus Holotype/richteri, sp.n. 59/ Stackelberg det.", "Holotypus '60/Eumerus/ richteri Stack." [red label] (ZISP).

Other material examined. Serbia: Dubašnica: $1 \hat{\jmath}, 3 q$, Lazar's river gorge, 1.vii.2019, leg. Vujić A. et al. Greece: Evros, 1오, Dadia, 26.-28.vii.2013, leg. Kourtidou M. (MAegean). Turkey: Isparta, Uluborlu: 1 , Kapıdağı, 24.vii.2014, leg. Hayat R. et al. (FSUNS).

Type locality. Lekedakh (Azerbaijan).

Distribution. This species is extremely rare in Southeast Europe. It is described from Azerbaijan and present in Turkey, Greece and Serbia (Fig. 1A).

Biology. This species is found in gorges at low altitudes in the Carpathian Mountains in Serbia and natural woodlands in Greece (Dadia). Larval stages undescribed. Flight period: June-August.

\section{Eumerus rubrum Grković \& Vujić in Grković et al., 2017}

Figs 5C, 8A

Grković et al., 2017: 185.

Diagnosis. Large species $(10-11 \mathrm{~mm})$ with predominantly orange to red abdomen. Eyes nearly bare. Ocellar triangle wider than long. Antenna small, yellow, slightly larger in female. Tergum I yellow to red posteriorly. Ventral pilosity on metafemur long, white and dense. This species is very similar to E. tauricus. The features that distinguish E. rubrum and E. tauricus are described in detail in Grković et al. (2017). Metafemur in female yellow to translucent (Fig. 8A).

Type material examined. Holotype $\delta$ : Greece: Peloponnese: Achaia, from Chelmos Mountain above Kalavryta, 16.v.2007; leg. Dils J., Faes J., Langemark S. (NBC). Paratype ${ }_{+}$: Greece: Laconia: Varvara, shelter of Taygetos, 02.vi.1993; leg. den Hollander G. (NBC).

Type locality. Chelmos Mountain (Greece).
Distribution. This species is extremely rare in Southeast Europe. It is only known from two localities on mainland Greece (Pelloponese and Laconia) (Fig. 1A).

Biology. This species is found in shrubby Mediterranean vegetation at high altitudes, herbaceous plant rich open areas and dry pine forests. Larval stages undescribed. Flight period: May-June.

\section{Eumerus sinuatus Loew, 1855}

4F4, 7F, 11A3, F, H2, 12C

Loew, 1855: 692.

Diagnosis. Large species (9-12 mm) with long body pilosity. Antennae small, black (Fig. 11F1), in female enlarged and densely striated (Fig. 11F2). Vertex shiny, weakly punctuated. Eyes in male dichoptic (Fig. 4F4). Colour of pilosity on the mesonotum varies from yellow to black. Terga with triangular red markings laterally (Fig. 11A3). The female could be confused with the female of $E$. ovatus, but they are most easily distinguished by the appearance of the antenna which is irregularly striated with many long furrows in E. sinuatus (Fig. 11F2) and evenly striated with around six furrows in E. ovatus (Fig. 11E2). In females of $E$. sinuatus, the distance between upper corner of the eye and posterior ocellus is approximately the same as the distance between posterior and anterior ocellus. Posterior lobe on male epandrium simple with protruding ventral margin (Fig. 12C).

Type material examined. Holotype $q$ : Austria: "Wien/ Schiner", "Coll. / H. Loew”, "Zool. Mus. / Berlin", "Eumerus + / sinuatus Lw. / det. D. Doczkal 1999" (ZMHB). Loew (1855) states that he had only one female of the new species at hand and because the specimen we consider to be that female holotype is not properly labeled, we attach a new label with: "Holotype + / Eumerus sinuatus / Loew, 1855 / design. Vujić, 2021" [red label].

Other material examined. Croatia: Istra: $6 \hat{\jmath}$, Motovun, 9.vi.2019, leg. Vujić A. et al.; 2خ, 1ㅇ, Červar Porat, 9.vi.2019, leg. Vujić A. et al. (FSUNS); 1§̄, Novi, Bribir, 11.vi.1969, 2 ㅇ, 


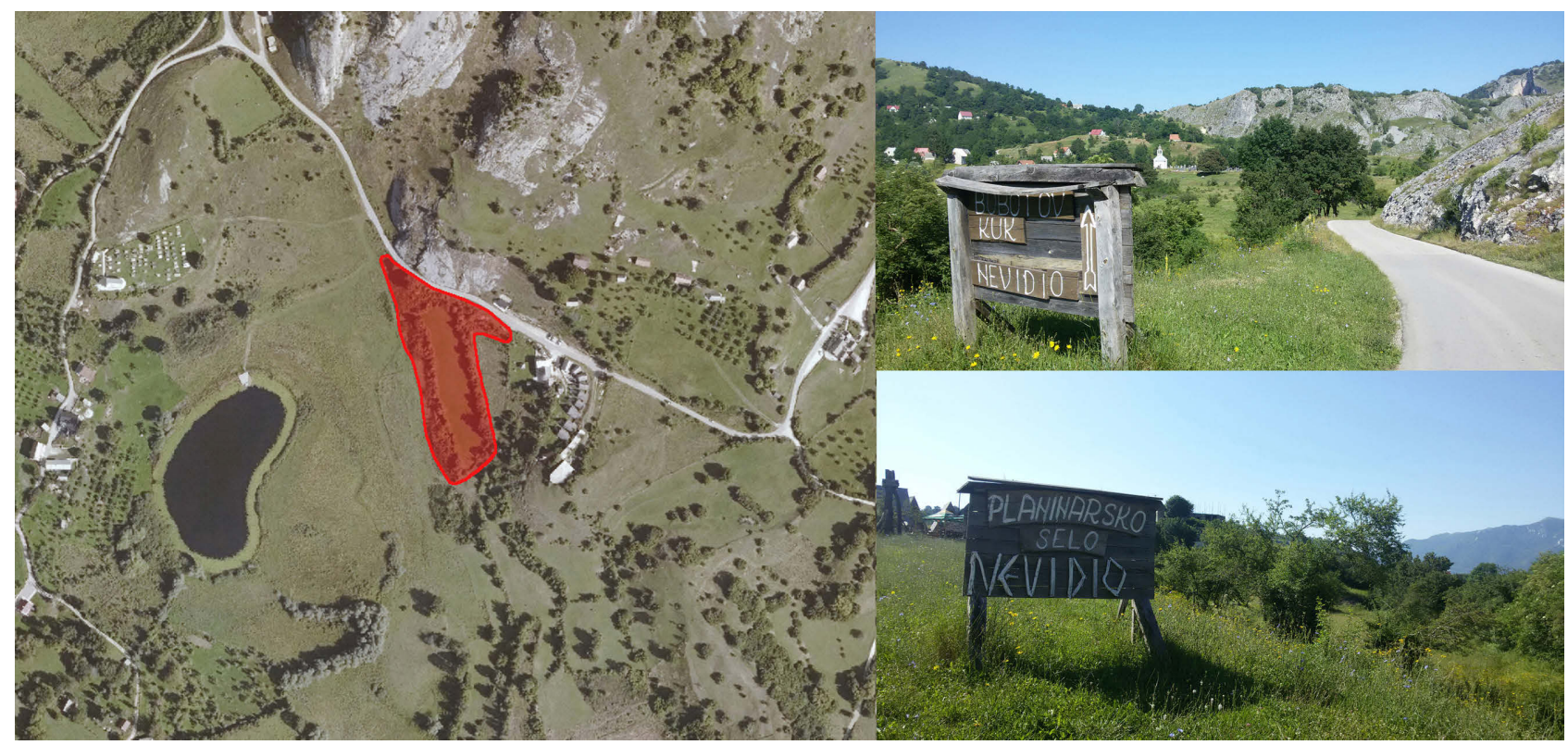

Fig. 16. Type locality of Eumerus nigrorufus Grković et Vujić, sp. n., meadow near the village Pošćenje on Durmitor Mountain (Montenegro). Photo: Ana Grković.

17.vi.1969, leg. Lambeck H.J.P. (NBC). France: Bas Rhin, Sélestat: 8ठ, Foret d'Ill 23.vi.2005, leg. van Steenis J., van Steenis W., van Zuijen M.P. (SJ coll, WS); Gers: 1§, Pichoy (Fources), 23.iv.2006, leg. Pennards G.W.A. (GP). Italy: Piemonte: $1 \hat{\jmath}$, Mt. Musine, 4.vi.1978, leg. Pagliano (NBC). Serbia: Fruška Gora: 1今̄, Glavica, 2.vii.2013., leg. Vujić A. (FSUNS).

Type locality. "Wien" (Austria).

Distribution. This species is rare in Southeast Europe. It is found in central and southern France, southern Germany (possibly Bavaria and Baden-Wuerttemberg), Austria, Hungary, Slovakia, Croatia, Montenegro, Serbia and Greece (Fig. 1D). Present also in northern Italy (Bolzano) (Sommaggio D., pers. comm.).

Biology. This species prefers open ground in deciduous forest and dry scrub woodland of Quercus pubescens Willd. with open areas (Speight, 2020). Larval stages undescribed. Flight period: May-August.

\section{Eumerus tarsalis Loew, 1848}

Figs 4F2, 5D, 6B, F, I, 7D

Loew, 1848: 113.

Diagnosis. Middle-sized species $(9-10 \mathrm{~mm})$ with very short body pilosity. Eyes almost bare, in male slightly separated (Fig. 4F2). Ocellar triangle wider than long. Antenna small, dark (Fig. 6F). Terga II-IV predominantly red (Fig. 6B). First three segments of pro- and mesotarsus yellow, with black patches basally, last two segments dark (Fig. 6I). Could be confused with E. sabulonum, a species widely distributed in Europe, but differs from it in that in males the eyes meet over a greater length, are slightly closer to each other and by the shape of male's genitalia (Fig. 5D). Male's epandrium simple, bent backwards, with longe pile dorsally (Fig. 5D).

Type material examined. Lectotype $\widehat{\jmath}$ (hereby designated to maintain taxonomic stability): Austria: "Wien / Megerle", "Coll
/ H. Loew", "illegible Em. trico, / lor Sturm", "Typus" [faded red label], "Eumerus / tarsalis / m.", "Zool. Mus. / Berlin",

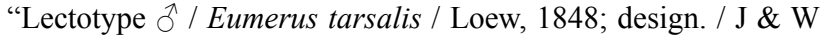
van Steenis, 2016" [red label], "QR code http://coll.mfn-berlin. de/u/dbc6f0" (ZMHB). There are several supposed syntypes in ZMHB, but Loew $(1848,1855)$ did not specify the number of syntypes and we only labelled the lectotype.

Other material examined. France: 1엉 Nemours, 3.vii.1923, 10ิ, Saint Geniez de Dromon, 5.vi.1948. (MNHN); Hautes Alpes, Vallouise: $1 \hat{\jmath}$, valle de l'Onde, 30.vi.1990, leg. van Steenis J. (JS). Montenegro: Maglić: 1ð, Stabansko jezero, 4.vii.2017, leg. Vujić A., Ačanski J., Kočiš Tubić N.; 19, Mratinje, 5.vii.2017, leg. Vujić A., Ačanski J., Kočiš Tubić N. (FSUNS).

Type locality. Central Europe.

Distribution. This species is found in central and southern Europe, North Africa, Russia and Mongolia. In Southeast Europe it is very rare, found only in Slovenia and Montenegro (Fig. 1C).

Biology. This species is found in both coniferous and deciduous forests, usually at high altitudes on alpine pastures up to over 2,000 $\mathrm{m}$ in the Alps, and in the Pinus mountain forests in southern Europe (Speight, 2020). Larval stages undescribed. Flight period: May-August.

\section{Eumerus tricolor (Fabricius, 1798)}

Figs 5E, 6C, G, H2

Syrphus tricolor Fabricius, 1798: 563.

Eumerus varius Meigen, 1822: 205, syn. n.

Diagnosis. Middle-sized species (7-12 mm) with very short body pilosity. Terga II-III red, tergum II with black triangular marking antero-medially (Fig. 6C). Antenna small and dark brown (Fig. 6G). Eyes covered in dense short pilosity, in male eyes are slightly separated. Males epandrium simple, upright, oval apically (Fig. 5E).

Type material examined. Lectotype $q$ of Syrphus tricolor Fabricius, 1798 (designated here to maintain taxonomic stabil- 
ity): Two specimens (male and female) in the Fabricius collection in ZMUC have been examined, both are badly damaged (male specimen with mesonotum and one wing, female specimen with thorax, a few legs and part of the abdomen). Both are labelled "type" and "244.52", male specimen also bears a label "tricolor خ̄". Female is designated here as lectotype due to preservation of more diagnostic characters on the remaining parts of the body and is labeled with: "Lectotype + / Eumerus tricolor / (Fabricius, 1798) / Design. Vujić, 2021". Paralectotype $\widehat{\partial}$ of Syrphus tricolor Fabricius, 1798: Male specimen becomes a paralectotype and is labeled: "Paralectotype $\widehat{\sigma} /$ Eumerus tricolor / (Fabricius, 1798) / Design. Vujić, 2021".

Lectotype of Eumerus varius Meigen, 1822 (designated here to fix the concept of varius and to ensure universal and consistent interpretation of the name): "1336/40", "Eumerus varius / §̊ Bhm.", "SYNTYPE" [red label], "MNHN, Paris / ED 4113", "Lectotype $\widehat{~}$ / Eumerus varius / Meigen, 1822 / Design. Vujić, 2021" [red label], "Eumerus tricolor / (Fabricius, 1798) / Det. Grković, 2021". Paralectotype $\delta$ of Eumerus varius Meigen, 1822: "1336 / 40", "SYNTYPE" [red label], "MNHN, Paris / ED 4112", "Paralectotype đ / Eumerus varius / Meigen, 1822 / Design. Vujić, 2021" [red label], "Eumerus tricolor / (Fabricius, 1798) / Det. Vujić, 2021". Meigen described E. varius based on an unspecified number of males and females. We examined two male syntypes of E. varius from Meigen's collection in MNHN and since they belong to E. tricolor, we designated one of them as lectotype of $E$. varius and the other is labelled as paralectotype.

Other material examined. Greece: Peloponnese, Ioninna: $4 \hat{\jmath}$, Konitsa, 4.vi.2017, leg. Vujić A. et al.; 2ત, Eleftero, 5.vi.2017, leg. Vujić A. et al.; 10̄, Chelmos-Kalavryta, 8.vi.2017, leg. Vujić

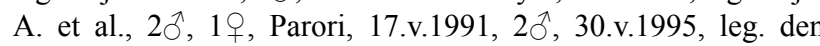
Hollander G.; Euboea: 20, Amarynthos, 24.iv.1997, leg Lucas J.A.W.; Fokida: 1ð, Delfi, 24.iv.1990, leg. Lucas J.A.W (NBC); Corfu: 3ㅇ, 1今, Strinilas, 24.-25.v.2016, leg. Vujić A. et al.; Chalcidice: 4⿳亠丷, Kassandra, 18.v.1997, leg. Vujić A. (FSUNS); 1§̃, Vaila Saka-Peristeri, 31.v.2015, leg. de Courcy Williams, M. (MCW); Sterea Ellada: 1q, Fthiotida, Mt. Iti South of Iti, 15.v.2012, leg. van Steenis J. (JS). Montenegro: Plužine: $1 \hat{\jmath}$, Stabansko jezero, 4.vii.2017; $3 \hat{\jmath}, 3$, , Mratinje, 5.vii.2017; Durmitor: $1 \hat{\jmath}$, Jablan lake, 10.viii.2013, leg. Vujić A. et al. (FSUNS); $1 \widehat{\jmath}$, Gorge of Sevjernica, 30.v.2017, leg. Malidžan S. (MNHP), 1ठิ, 21.vi.2019; Orijen: 21ð, 2ᄋ, Gornji Orijen, 21.vi.2019; Lovćen: 1, 20.vi.2019, leg. Vujić A. et al. (FSUNS). Netherlands: Wijlre: $1 \hat{\jmath}$, Wrackelberg, 7.vi.2014, leg. van Steenis J. (JS); Valkenburg: 1ठ, 1으, Gerendal "Orchidee tuin", 7.vi.2014, leg. van Steenis J. (JS). Slovenia: Slovenia Notranjska: $1 \hat{\jmath}$, Ilirska Bistrica Volovja Reber, 20.vi.2008, leg. van Steenis J., van Steenis W. (WS).

Type locality. Switzerland.

Distribution. This species is recorded in the Netherlands south to the Mediterranean; from Belgium eastwards through central Europe to European parts of Russia; through Siberia to the Pacific coast (Speight, 2020) (Fig. 1C).

Biology. This species prefers scrub, hedgerows, dry unimproved and permanent pasture, including montane grassland (Speight, 2020). The larva and puparium are described by Arzone (1971). It is considered to be a pest of Tragopogon porrifolius L. (Arzone, 1973). Flight period: May-August.

\section{Eumerus binominatus subgroup}

Eumerus binominatus subgroup sensu Grković et al., 2019b.

\section{Eumerus tenuitarsis Grković \& Vujić in Grković et al., $2019 b$}

Figs 7A, 8B, 11A4, G1, H3

Grković et al., 2019b: 100.

Diagnosis. The only known member of the E. binominatus subgroup in Southeast Europe. Large species (11-12 $\mathrm{mm}$ ) in which the segments in the metaleg of males are very long (Fig. 7A) and with long body pilosity. Antenna small and dark. Eyes slightly separated in male, meeting over a short distance. Metatibia with a characteristic curvature in the posterior half, also noticeable in females (Fig. 8B). The constriction of the elongated metafemur is located in the anterior half, which distinguishes it from the similar European species E. grallator Smit, 2019 from Spain, in which the constriction is located in the posterior half. Posterior lobe on male epandrium simple, with the top slightly bent ventrally (Fig. 12D).

Type material examined. Holotype $\delta$ : Greece: Lesvos, Agiassos. Original label: "Agiassos, $601 \mathrm{~m} /$ Lesbos, Greece / $39^{\circ} 4^{\prime} 16^{\prime \prime} \mathrm{N} / 26^{\circ} 22^{\prime} 23^{\prime \prime} \mathrm{E} / 23 . v i .2003$ / leg. M. Hull” (FSUNS). Paratype $\bigcirc$ : Greece: Evros, Dadia, 26.-28.vii.2013, 40.9943N 26.0933E leg. Kourtidou M. (FSUNS).

Other material examined. Turkey: Isparta: Yenişarbademli, 3ㅇ, Melikler Yaylas1, 26.vii.2014, leg. Hayat R. et al. (FSUNS); Turkey: Antalya, Irmesan Gedigi, $1+, 12 \mathrm{~km} \mathrm{~N}$ of Ankara, 25.vii.1981, leg. Coene H., Lucas J., Oorschot B.V. (NBC).

Type locality. Lesvos (Greece).

Distribution. This species is extremely rare in Southeast Europe. It is only known from two localities in Greece (Lesvos, Evros) and from Turkey (Isparta) (Fig. 1D).

Biology. It is found in open areas in Castanea and thermophilous Quercus forest. Larval stages undescribed. Flight period: June-July.

\section{Key for Southeast European species of the Eumerus tricolor group}

Males

1 Eyes bare or nearly bare (as in Figs 4F1, F2) ..................... 2

- Eyes covered with conspicuous pilosity (as in Figs 4F3, F4, 6D2, 9C, 11B).

2 Antenna yellow, large, about $1 / 3$ of the height of the head (as in Fig. 4B1). Tarsal segments short, metabasitarsus longer than the other tarsal segments on the same leg combined (as in Fig. 4E1, E2). Ocellar triangle isosceles, closer to eye contiguity than upper eye margin ............................................... 3

- Antenna small, about 1/4 of the height of the head (as in Fig. $6 \mathrm{~F} 1$ ), yellow or brown. Tarsal segments of normal length. Ocellar triangle wider than long or equilateral, closer to upper corner of eye than to eye contiguity ..................................... 4

3 Ventral pilosity on metafemur short (Fig. 4E2). Male genitalia as in Fig. 5A1-A4 (Greece: Lesvos, Rhodes, Samos)........ Eumerus armatus

- Ventral pilosity on metafemur very long (Fig. 4E1). Male genitalia as in Fig. 5B1, B2 (Montenegro) ..... Eumerus nigrorufus sp. n.

4 Antenna yellow. Protarsus and mesotarsus dark. Tergum I yellow posteriorly. Male genitalia as in Fig. 5C.....

Eumerus rubrum 
- Antenna dark (Fig. 6F1). Protarsus and mesotarsus with first three segments yellow, with black spot basally and segments IV-V black (Fig. 6I). Tergum I black, sometimes with yellowish posterior margin (Fig. 6B1). Male genitalia as in Fig. 5D ............................................................ Eumerus tarsalis

5 Eyes clearly separated by the diameter of an ocellus or more

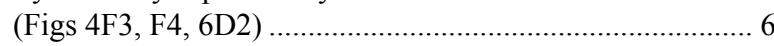

- Eyes connected or almost so (as in Figs 9C, 11C).............. 10

6 Pilosity on mesonotum (as in Fig. 11G1) and sternum II (as in Figs $6 \mathrm{H} 1,11 \mathrm{H} 2, \mathrm{H} 3$ ) long and very dense .......................... 7

- Pilosity on mesonotum (as in Fig. 6D3) and sternum II very short (as in Fig. 6H2)...

7 Mesonotum dull, medium to densely punctuated with more or less visible pollinose vittae. Terga without clear red markings (as in Figs 6A1, 11A4)...

- Mesonotum shiny, weakly punctuated and nonpollinose. Terga with large red markings laterally (Fig. 11A3), medially black. Male genitalia as in Fig. 12C ............Eumerus sinuatus

8 Antenna dark. Segments of metaleg very long (Fig. 7A). Apical half of metafemur narrow (Fig. 7A) and with reduced, very short and scattered ventral spinae. Abdomen heartshaped, pointed (Fig. 11A4). Male genitalia as in Fig. 12D... Eumerus tenuitarsis

- Antenna yellowish to red (Fig. 6E1). Segments of metaleg of normal length (Fig. 7E), metafemur apico-ventrally with two rows or regular spinae. Abdomen gradually narrows towards the tip (Fig. 6A1). Male genitalia as in Fig. 3E

Eumerus richteri

9 Antenna dark (Fig. 6G1). Metafemur moderately thickened. Terga II-III mostly red, tergum II with characteristic black triangular marking medially (Fig. 6C1). Male genitalia as in Fig. 5E Eumerus tricolor

- Antenna reddish, brighter basally (Fig. 6D4). Metafemur strongly thickened (Fig. 7B). Terga black an characteristically with adpressed yellow to gold pilosity on tergum IV (Fig. 6D1). Male genitalia as in Fig. 3D ............ Eumerus aurofinis

10 Mesonotum black, covered in short, predominantly yellow pilosity (as in Fig. 10D).

- Mesonotum shiny blue, covered in long, snow-white or blac pilosity (as in Figs 11B, G2)...................................

11 Mesofemur flattened basally (Fig. 10A: a). Metafemur ventrally very shiny with very short scarce pilosity (Fig. 10B). Terga black without red markings (Fig. 9A1). Male genitalia as in Fig. 3C.

Eumerus crispus sp. n.

- Mesofemur moderately thickened. Metafemur with longer pile ventrally. Terga II-III usually with red markings laterally (Fig. 9D2), sometimes very reduced (Fig. 9D1). Male genitalia as in Fig. 3B.

. Eumerus grandis

12 Terga II-IV with large red areas laterally. Terga III-IV with characteristic silvery-white pilosity giving the abdomen a velvet appearance (Fig. 11A2). Eyes covered in long dense pilosity, with a very narrow gap in between them (Fig. 11C). Metatibia without characteristic snow-white pilosity depicted in Fig. 7C. Male genitalia as in Fig. 12B.......Eumerus ovatus Terga II-IV black with metallic blue shine (Fig. 11A1), rarely with small reddish patches laterally on tergum II and III. Eyes clearly connected, covered in very dense and long pilosity (Fig. 11B). Metatibia dorsally covered in snow-white characteristic pilosity (Fig. 7C). Male genitalia as in Fig. 12A .........

Eumerus niveitibia

\section{Females}

1 Eyes bare or nearly bare (as in Figs 4F1, F2) ..................... 2

- Eyes covered with conspicuous pilosity (as in Figs 4F3, F4, $6 \mathrm{D} 2,9 \mathrm{C}, 11 \mathrm{~B})$
2 Basoflagellomere dark, small, less than 1.5 times wider than the pedicel (Fig. 6F2). Protarsus and mesotarsus with first three segments yellow, with black spot basally and segments IV-V black (as in Fig. 6I).......................... Eumerus tarsalis - Basoflagellomere yellow, more than 1.5 times wider than the pedicel (as in Fig. 4B2). Protarsus and mesotarsus dark ...... 3

3 Basoflagellomere small, about 1.5 wider than the pedicel. Frons approximately twice the width of the basoflagellomere. Metafemur yellow (Fig. 8A)....................... Eumerus rubrum

- Basoflagellomere greatly enlarged, twice as wide as pedicel or more (Fig. 4B2). Frons narrow or just as wide as the basoflagellomere. Metafemur black (Fig. 4C). Greece or Montenegro ............ Eumerus armatus or Eumerus nigrorufus sp. n.

4 Metafemur and metatibia very slender and elongated, apicoventral spinae tiny, short and sparse (Fig. 8B). Basoflagellomere small, less than 1.5 times wider than the pedicel. Metatibia with characteristic curvature (Fig. 8B). Abdomen pointed, heart-shaped (as in Fig. 11A4).. Eumerus tenuitarsis Metafemur and metatibia less or more thickened. Metafemur with regular apicoventral rows of spinae.......

5 Mesonotum (as in Fig. 11B) and abdomen (as in Figs 11A1) black with clear metallic blue shine, covered in dense and long snow-white or black pilosity. Terga II and III sometimes with small reddish markings laterally. Metatibia dorsally covered in snow-white characteristic pilosity (Fig. 8D)

Eumerus niveitibia

Mesonotum black, sometimes with bluish tinge .................. 6

6 Pilosity on mesonotum long (as on Fig. 11G2) .................... 7

Pilosity on mesonotum short (as on Figs 6D3, 10D)............ 8

7 Basoflagellomere moderately striated (Fig. 11E2)

Eumerus ovatus

- Basoflagellomere densely striated over the entire surface (Fig. 11F2) ...............................................Eumerus sinuatus

8 Antenna yellow or reddish (Figs 6D5, E2) .......................... 9

- Antenna dark (Figs 6G2, 9B2) ......................................... 10

9 Eyes covered in short, dense white pilosity (as in Fig. 4F3). Metafemur moderately thickened, covered with dense white pilosity (Fig. 8E) ........................................ Eumerus richteri Eyes covered with tiny, scattered pilosity (as in Fig. 6D2). Metafemur strongly thickened and covered in extremely short yellow pilosity (Fig. 8C)... Eumerus aurofinis

10 Basoflagellomere small, less than 1.5 times wider than the pedicel (Fig. 6G2). Mesonotum with triangular pollinose markings anteriorly, which sometimes extend into narrow lines....................................................... Eumerus tricolor Basoflagellomere greatly enlarged, about twice as wide as pedicel (as in Fig. 9B2). Mesonotum with strong pollinose vittae

11 Ventral pile on metafemur longer than the apicoventral spinae (Fig. 10F: b) ............................................ Eumerus grandis - Ventral pile on metafemur shorter than the apico-ventral spinae (Fig. 10C: b)..... Eumerus crispus sp. n.

\section{Molecular data}

Based on the COI gene sequences, a genetic analysis was done in addition to the morphological description of the Eumerus tricolor species group in Southeast Europe. COI gene sequences of 43 specimens in total, including 33 samples belonging to the E. tricolor species group, along with eight samples of other major Eumerus species groups, and Archimicrodon sp. and Xanthogramma citrofasciatum De Geer, 1776 as outgroups, were analysed. Accession numbers of retrieved gene sequences from GenBank and newly produced sequences are listed in Table S1. The final data- 
set of combined sequences of 3'- and 5'-ends of COI gene comprised 1290 base pairs, with 350 parsimony informative characters. The two obtained trees, Maximum Parsimony (Fig. 13) and Maximum Likelihood (Fig. 14), had the same topology for the species group examined. The monophyly of the group was confirmed (bootstrap values MP = $100, \mathrm{ML}=100)$, as previously reported by Chroni et al. (2017) and Ricarte et al. (2018). In accordance with those authors, both analyses, MP and ML, yielded trees with two main clusters. One cluster consisted of taxa belonging to the E. tricolor group (10 taxa) with the second comprising representative species of the other Eumerus groups. All analysed taxa of the E. tricolor group were clearly separated from each other, with high bootstrap nodal support values on both trees: $E$. armatus $\mathrm{MP}=90, \mathrm{ML}=96 ; E$. nigrorufus Grković \& Vujić, sp. n. $\mathrm{MP}=99, \mathrm{ML}=100$; all the others $\mathrm{MP}=100, \mathrm{ML}=100$. Branching topology for the group was consistent across the analyses. The topologies resolved the following relations among species of the group: E. tricolor $+((E$. tenuitarsis $+E$. aurofinis $)+((E$. nigrorufus sp. n. + E. armatus $)+((E$. sinuatus $+E$. ovatus $)+($ E. niveitibia $+($ E. crispus sp. n. + E. grandis $)))))$. The two newly described species, E. nigrorufus Grković \& Vujić, sp. n. and E. crispus Vujić \& Grković, sp. n, cluster together with the morphologically similar species of the group, E. armatus and E. grandis, respectively, but within clades were clearly separated from each other and strongly supported by bootstrap values. After the first implementation of molecular tools (COI-3') to infer species delimitation in the genus Eumerus (Chroni et al., 2017) and using COI barcodes (COI-5') to get insights into the taxonomy of the E. tricolor group (Ricarte et al., 2018), here we used the COI-gene based system (COI-3'+COI-5') for Eumerus taxonomic inference of 33 specimens of the group assigned to 10 taxa. The results confirmed the morphological species assignment and successful use of the mitochondrial COI gene in species diagnosis in the E. tricolor species group. In agreement with Chroni et al. (2017) and Ricarte et al. (2018), the E. tricolor species group is genetically and morphologically well defined.

\section{Diversity of Eumerus tricolor group in Europe}

The Eumerus tricolor group includes over 20 species in Europe. Out of that number, 13 species are recorded in the southeastern part. The species of the E. tricolor group are morphologically very diverse, but in comparison to other groups of the genus, they are clearly separated by a set of apomorphic characters. There are a number of studies on the E. tricolor group in Europe. Grković et al. (2017) describe a new species, E. rubrum and define the group. They list eleven species belonging to the E. tricolor group on the Balkan Peninsula and eastern Mediterranean islands, including E. tauricus. Grković et al. (2019b) define the $E$. binominatus subgroup within the E. tricolor group, which consists of long-legged species, with two European members, E. grallator from Spain and E. tenuitarsis, found in Greece. Ricarte et al. (2018) describe a new species from Spain, E. azabense Ricarte \& Marcos-García, 2018, des- ignate the neotype for the most closely related species, $E$. niveitibia and confirm the monophyly of the group.

As with other Eumerus species, the development of larvae of the E. tricolor group is dependent on the presence of the host plant. They usually develop in damaged underground storage organs of geophytes, but also in other decaying plant tissues (Rotheray \& Gilbert, 1999; Ricarte et al., 2017; Souba-Dols et al., 2020). Of the total number of more than 300 described species of Eumerus (Evenhuis \& Pape, 2021), early stages are described for only 13 species, and for less than 30 species the host plants are reported (Souba-Dols et al., 2020), including the most recently discovered E. platycodon Choi \& Hong, 2021, species from the E. tricolor group, infesting roots of Campanulaceae crops in South Korea (Deuk-Soo et al., 2021). Within the E. tricolor group, the host plants are known only for three European species (Ricarte et al., 2017). The egg, larva, head skeleton and puparium of E. tricolor are described by Arzone (1971), a species the larvae of which feed on Goatsbeard (Tragopogon pratensis L., Asteraceae) (Arzone, 1971, 1973), a widespread Eurasian species of plant also found in the Nearctic region and New Zealand. The other two species from this group for which there is some developmental data are E. etnensis Goot, 1964 (as E. purpurariae Baez, 1982), for which Pérez-Bañón \& MarcosGarcía (1998) describe the egg, larva, head skeleton and puparium, and E. sabulonum (Fallén, 1817), whose larval stages are not yet described, but females are recorded ovipositing on rosettes of young Sheepbit (Jasione montana L., Campanulaceae) (Munk, 2000). Eumerus etnensis is a western Mediterranean species, developing in platyclades of Opuntia maxima Mill. (Cactaceae) (Pérez-Bañón \& Marcos-García, 1998). E. sabulonum is much more widespread in Europe, but rare, and in Germany assessed as Endangered (Ssymank et al., 2011). Both of the latter species are not present in Southeast Europe and E. tricolor is thus the only SE European species with some biological data related to larval development. At the same time, this is the most widespread species of the group, both in Europe and in the whole of Eurasia, found from western Europe to Far Eastern Siberia (Speight, 2020). There are few widely distributed species in the E. tricolor group, one of them is E. tarsalis, which is found from Spain to Siberia and Mongolia (Speight, 2020), but considered to be very rare and endangered in Europe (A. Grković, unpubl.) and extinct or possibly extinct in some countries (Farkač et al., 2005; Ssymank et al., 2011; Speight, 2020). Eumerus grandis, found from western Europe to eastern Asia, which is very similar to the newly described E. arctus sp. n., E. crispus sp. n. and the recently described E. platycodon from South Korea (Deuk-Soo et al., 2021), is already listed as extinct in Germany (Ssymank et al., 2011) and endangered in Sweden (Artdatabanken, 2020). In Europe, the widespread $E$. ovatus and E. sinuatus are considered as rare and endangered with very fragmented populations (A. Grković, unpubl.). All other species in this group are more or less locally distributed with some threatened according to the IUCN (A. Grković, unpubl.). 


\section{Small patches of habitat}

Ten different Eumerus species, E. aff. sulcitibius, E. amoenus Loew, 1848, E. argyropus Loew, 1848, E. consimilis Šimić \& Vujić, 1996, E. grandis, E. hungaricus Szilády, 1940, E. montanum Grković, Radenković \& Vujić, 2017, E. nigrorufus sp. n., E. sulcitibius Rondani, 1868 and E. tricolor, have been collected in the locality Komarnica in Montenegro, and E. nigrorufus sp. n. is only recorded from there. Three of them belong to the E. tricolor species group: E. grandis, E. nigrorufus sp. n. and E. tricolor. The size of the patch of habitat where sampling was conducted was only 0.9 ha. The size of locality Grabovo in Serbia, which is the sole locality of E. crispus sp. n., is 0.17 ha and hosts 4 different Eumerus species: E. argyropus, E. basalis Loew, 1848, E. crispus sp. n. and E. tricolor, the last two belong to the tricolor group.

The significance of the size of an area in terms of its conservation potential is the subject of many past studies (Fischer et al., 2010; Tulloch et al., 2016; Wintle et al., 2019). The general premise is "the bigger, the better", with the main argument being that large areas provide a large spectrum of suitable conditions for different species (Worboys et al., 2010; Mortelliti et al., 2014). However, spatial scale should be taken into consideration when addressing this question. As shown in the example of two species from the E. tricolor group, described in this paper, small patches of habitat might prove to be essential for the preservation of these species.

The most obvious example is the locality Komarnica, in Montenegro, which hosts 10 different Eumerus species. This locality $\left(42^{\circ} 58^{\prime} 39.78^{\prime \prime}, 19^{\circ} 4^{\prime} 18.68^{\prime \prime}\right)$ is found near the canyon of the river Komarnica, close to two lakes: Big and Small Pošćenje Lake. Interestingly, this patch of habitat is very close to two protected areas: National Park Durmitor and Nature Park Dragišnica and Komarnica, but it is not encompassed by either of them. This habitat borders on a mixture of mountain hay meadows and wooded meadows (Petrović et al., 2019). The specific combination of climatic and orographic conditions, where Mediterranean and mountain zones overlap, has resulted in the formation of microclimatic conditions and specific micro-habitats. In this way, one kind of micro-hotspot for species of Eumerus was created. Considering that a species described here, E. nigrorufus sp. n. is so far only known to occur in this particular patch of habitat, in spite of extensive searching, not only in the surrounding area, but across Durmitor and Komarnica in general, we presume that a hitherto unknown combination of local parameters has a very significant role in the survival of this, but also other Eumerus species found at this locality. However, the plan to construct a hydroelectric power plant on the river Komarnica (Europroject Architecture and Engineering, 2020) would have a tremendous negative effect on this patch of habitat, which is in the zone of the intervention plan, and thus on the species found within the patch. In order to preserve this micro-hotspot any change in the structure of the area should be avoided. The first step in accomplishing this would be to include this locality as a part of one of the surrounding protected areas. In addition, it is important to consider the effect of potential habitat disruptions not only on freshwater invertebrates, directly affected by the construction of a hydroelectric power plant, but on terrestrial ones as well. Phytophagous hoverflies are recognized as good bioindicators (Popov et al., 2017) and could shed light on the extent of the negative consequences of these types of changes.

A second example of the significance of small patches of habitat comes from Serbia. Fruška Gora mountain, declared a National Park, is the dominant feature in the south of the Pannonian plain. It is primarily a forest area, with a small amount of meadow-steppe and forest-steppe vegetation, shrubs and hedges (Gavrilović et al., 2014). Grabovo pastures, a locality on the northern slopes of the Fruška Gora mountain, encompasses forest steppe and steppe areas found on the slopes along the stream. Here, Ornithogalum sphaerocarpum A. Kern. (Asparagaceae), a rare bulbous plant occurs at a few localities on Fruška Gora (Obradović, 1966). In addition, Gentiana cruciata L. (Gentianaceae) is recorded, which is extremely rare in the Pannonia lowlands and it is presumed that Grabovo pastures is the only recent habitat of this species in the northern part of Serbia. Two rare bird species, European honey buzzard (Pernis apivorus (Linnaeus, 1758)) and Ortolan bunting (Emberiza hortulana Linnaeus, 1758), are recorded in this area as well, which is why the Provincial Institute for Nature Conservation of Vojvodina province several years ago proposed widening the borders of the national park, in order to encompass this important locality (Institute for Nature Conservation of Vojvodina Province, 2015).

The plot named Grabovo sampled in our study $\left(45^{\circ} 10^{\prime} 19.38^{\prime \prime}, 19^{\circ} 37^{\prime} 8.72^{\prime \prime}\right)$ in which E. crispus sp. n. was recorded, is some $50 \mathrm{~m}$ outside the border of the national park. Considering that this species is apparently associated with steppe areas and it is not found deeper in the forest, it is essential to maintain a moderate level of human activity in this area, in order that this fragment of steppe remains in its current state and avoid succession towards a forest ecosystem, while, on the other hand, overgrazing should be avoided.

ACKNOWLEDGEMENTS. We thank M. Hauser (Sacramento, USA) for sending material of European Eumerus species. O. Ovchinnikova and N. Paramonov (St. Petersburg, Russia) and S. Blank (Müncheberg, Germany) for loan of material. J. Pohl for sending detailed photographs of the type material from Museum für Naturkunde in Berlin. T. Tot for field work and the photograph of locality Grabovo. The second author is grateful to the Dutch Uyttenboogaart-Eliasen foundation for its financial support under numbers SUB.2014.12.16 for the visit to St Petersburg. The authors acknowledge financial support of the Ministry of Education, Science and Technological Development of the Republic of Serbia (Grant Nos. 451-03-9/2021-14/ 200125 and 451-03-9/202114/200358) and H2020 Project ANTARES (grant No. 664387).

\section{REFERENCES}

Artdatabanken 2020: Red-listed species in Sweden 2020. SLU, Uppsala, 241 pp. [in Swedish].

Arzone A. 1971: Reperti biologici su Eumerus tricolor Meigen, nocivo alle coltivazioni di Tragopogon porrifolius L. in Pie- 
monte (Dipt. Syrphidae). — Ann. Fac. Sci. Agr. Univ. Torino 7: $17-52$.

Arzone A. 1973: Tragopogon pratensis L., ospite natural di Eumerus tricolor Meigen (Dipt. Syrphidae). - Ann. Fac. Sci. Agr. Univ. Torino 8: 55-66.

Bartsch H., Binkiewicz E., Klintbjer A., RÅdén A. \& Nasibov E. 2009: Diptera: Syrphidae: Eristalinae and Microdontinae. The National Key to Swedish Flora and Fauna, DH 53b. Artdatabanken, SLU, Uppsala, 478 pp. [in Swedish].

BeCKER T. 1921: Neue Dipteren meiner Sammlung. I. Syrphidae. — Mitt. Zool. Mus. Berl. 10: 1-93.

Blondel J. \& Aronson J. 1999: Biology and Wildlife of the Mediterranean Region. Oxford University Press, Oxford, 328 pp.

Chen H., Rangasamy M., Tan S.Y., Wang H. \& Siegfried B.D. 2010: Evaluation of five methods for total DNA extraction from western corn rootworm beetles. - PLoS ONE 5(8): e11963, 6 pp.

Chol D.S., PARK D.K., Lee Y.B. \& Hong K.J. 2021: A new species of the genus Eumerus (Diptera: Syrphidae) infesting roots of Campanulaceae crops in South Korea. - J. Asia Pac. Entomol. 24: 402-408.

Chroni A., Đan M., Vidaković D.O., Petanidou T. \& Vují A. 2017: Molecular species delimitation in the genus Eumerus (Diptera: Syrphidae). - Bull. Entomol. Res. 107: 126-138.

Chroni A., Grković A., Ačanski J., Vujić A., Radenković S., VeličKović N., Đan M. \& Petanidou T. 2018: Disentangling a cryptic species complex and defining new species within the Eumerus minotaurus group (Diptera: Syrphidae), based on integrative taxonomy and Aegean palaeogeography. - Contrib. Zool. 87: 197-225.

CuRTIS J. 1839: British Entomology; Being Illustrations and Descriptions of the Genera of Insects Found in Great Britain and Ireland. Vol. 16. Published by the author, London, plates 722-769.

DoczKal D. 1996: Description of two new species of the genus Eumerus Meigen (Diptera, Syrphidae) from Corsica. - Volucella 2: 3-19.

European COMmission 2020: Communication from the Commission to the European Parliament, the Council, the European Economic and Social Committee and the Committee of the Regions: EU Biodiversity Strategy for 2030. Bringing Nature back into our Lives. Brussels, 22 pp.

Europroject Architecture AND ENGINEERING 2020: Strategic Environmental Impact Assessment Report. Detailed Spatial Plan for the Space of Multipurpose Accumulation on the River Komarnica. Podgorica, Montenegro, 186 pp.

Evenhuis N.L. \& Pape T. 2019: Systema Dipterorum. Version 2.1. URL: http://www.diptera.org (last accessed 20 Apr. 2021).

FABRicius J.C. 1794: Entomologia Systematica Emendata et Aucta. Vol. 4. Christian Gottlob Proft, Copenhagen, 472 pp.

FABricius J.C. 1798: Supplementum Entomolgiae Systematicae. Hafniae [= Copenhagen], $572 \mathrm{pp}$.

FARKaČ J., KRÁL D. \& ŠKorpíK M. 2005: List of Threatened Species in Czech Republic: Invertebrates. URL: https://www. nationalredlist.org/red-list-of-threatened-species-in-the-czechrepublic-invertebrates-2005/

Fischer J., Sherren K., Stott J., Zerger A., Warren G. \& Stein J. 2010: Toward landscape-wide conservation outcomes in Australia's temperate grazing region. - Front. Ecol. Environ. 8: $69-74$.

Folmer O., Black M., Hoen W., Lutz R. \& Vrijenhoek R. 1994: DNA primers for amplification of mitochondrial cytochrome $\mathrm{c}$ oxidase subunit I from diverse metazoan invertebrates. - Mol. Mar. Biol. Biotechnol. 3: 294-299.
Gavrilović B., Gavrilović B., Ćurčić S., Stojanović D. \& Savić D. 2014: Leaf beetles (Coleoptera: Chrysomelidae) of Mt. Fruška Gora (Vojvodina Province, Northern Serbia), with an overview of host plants. - Šumarski List 138: 29-41.

Goloboff P.A. 1999: NONA Computer Program. Version 2.0. Tucuman (Argentina). URL: https://www.softpedia.com/get/ Scienece-CAD/NONA.shtml (last accessed 15 Feb. 2021).

Google Inc. 2020: Google Earth. Mountain View, California, USA. URL: https://www.google.com/earth (last accessed 15 Oct. 2020).

Grković A. 2018: Revision of the Genus Eumerus Meigen, 1822 (Diptera: Syrphidae) on Balkan Peninsula. PhD Thesis, University of Novi Sad, $281 \mathrm{pp}$. [in Serbian].

Grković A., Vujić A., Radenković S., Chroni A. \& Petanidou T. 2015: Diversity of the genus Eumerus Meigen (Diptera, Syrphidae) on the eastern Mediterranean islands with description of three new species. - Ann. Soc. Entomol. Fr. 51: 361-373.

Grković A., Vujić A., Chroni A., van Steenis J., Đan M. \& RADENKOVIĆ S. 2017: Taxonomy and systematics of three species of the genus Eumerus Meigen, 1822 (Diptera: Syrphidae) new to southeastern Europe. - Zool. Anz. 270: 176-192.

Grković A., van Steenis J., Kočiš Tubić N., Nedeljković Z., Hauser M., Hayat R., Demirözer O., Đan M., Vujić A. \& RADENKOVIĆ S. 2019a: Revision of the bactrianus subgroup of the genus Eumerus Meigen (Diptera: Syrphidae) in Europe, inferred from morphological and molecular data with descriptions of three new species. - Arthr. Syst. Phylog. 77: 21-37.

Grković A., Smit J., Radenković S., Vujić A. \& van Steenis J. 2019b: Two new European long-legged hoverfly species of the Eumerus binominatus species subgroup (Diptera, Syrphidae). -ZooKeys 858: 91-108.

Haddad N.M., Brudvig L.A., Clobert J., Davies K.F., Gonzalez A., Holt R.D., Lovejoy T.E., SeXton J.O., Austin M.P., ColLINS C.D. ET AL. 2015: Habitat fragmentation and its lasting impact on Earth's ecosystems. - Sci. Adv. 1(2): e1500052, 6 pp.

Hadley A. 2012: CombineZP 1.0 (computer software for image stacking). URL: https://combinezp.software.informer.com/ download/\#downloading

HäKkilä M., Johansson A., Sandgren T., Uusitalo A., MönkKÖNEn M., PUtTonen P. \& SAVIlaAkso S. 2021: Are small protected habitat patches within boreal production forests effective in conserving species richness, abundance and community composition? A systematic review. - Environ. Evid. 10(1): 2, $20 \mathrm{pp}$.

HaLL T.A. 1999: BioEdit: a user-friendly biological sequence alignment editor and analysis program for Windows 95/98/ NT. - Nucl. Acids Symp. Ser. 41: 95-98.

Institute for Nature Conservation of Vojvodina Province 2015: National Park Fruška Gora - Proposal for the Establishment of Protection of Natural Values, in the Process of Drafting the Law on National Parks. Novi Sad, 94 pp. [in Serbian].

KočIŠ Tubić N., StÅHLS G., AČAnSKI J., ĐAN M., OBReht VidaKović D., Hayat R., Khaghaninia S., Vujić A. \& RadenKović S. 2018: An integrative approach in the assessment of species delimitation and structure of the Merodon nanus species group (Diptera: Syrphidae). - Organisms Divers. Evol. 18: 479-497.

Kumar S., Stecher G. \& Tamura K. 2016: MEGA7: Molecular Evolutionary Genetics Analysis version 7.0 for bigger datasets. - Mol. Biol. Evol. 33: 1870-1874.

LoEw H. 1848: Über die europäischen Arten der Gattung Eumerus. - Stettin. Entomol. Ztg 9: 108-136.

Loew H. 1855: Über die Gattung Eumerus. - Verh. Zool.-Bot. Ges. Wien 5: 687-696. 
MeIGEN J.W. 1822: Systematische Beschreibung der Bekannten Europäischen Zweiflügeligen Insekten. F.W. Forstmann, Aachen, 416 pp.

Mortelliti A., Sozio G., Driscoll D.A., Bani L., Boitani L. \& LindenMaYer D.B. 2014: Population and individual-scale responses to patch size, isolation and quality in the hazel dormouse. - Ecosphere 5(9): 107, 21 pp.

MunK T. 2000: Eumerus sabulonum (Fallén, 1817) (Syrphidae, Diptera) breeds in Jasione montana L. - Flora og Fauna 106: 19-22 [in Danish, English abstract].

NiXon K.C. 2008: ASADO, Version 1.85 TNT-MrBayes Slaver Version 2; mxram 200 ( $v l$ 5.30). Made available through the author (previously named WinClada, version 1.00 .08 (2002). URL: http://www.diversityoflife.org/winclada (last accessed 15 Feb. 2021).

OBradović M.S. 1966: Plant-geographical Analysis of the Flora of Fruška Gora. Matica srpska, Novi Sad, 226 pp. [in Serbian]

PANZer G.W.F. 1798: Faunae Insectorum Germanicae Initia, oder Deutschlands Insecten. Heft 60, 24 pp. Felseckerschen Buchhandlung, Nürnberg.

Parks D.H., Mankowski T., Zangooei S., Porter M.S., ArMANini D.G., Baird D.J., LANGille M.G.I. \& BeIKo R.G. 2013: GenGIS 2: Geospatial analysis of traditional and genetic biodiversity, with new gradient algorithms and an extensible plugin framework. - PLoS ONE 8(7), e69885, 10 pp.

Peck L.V. 1988: Syrphidae. In Soós A. \& Papp L. (eds): Catalogue of Palaearctic Diptera 8. Akadémiai Kiadó, Budapest, pp. 11-230.

PÉrez-Bañón C. \& Marcos-García M.Á. 1998: Life history and description of the immature stages of Eumerus purpurariae (Diptera: Syrphidae) developing in Opuntia maxima. - Eur. J. Entomol. 95: 373-382.

Petrović D., Hadžiablahović S., Vuksanović S., Mačić V., Milanović Đ. \& LaKušIĆ D. 2019: Catalogue of Habitat Types of EU Interest in Montenegro, Version 3. Project: Establishments of Nature 2000 Network - Montenegro. EuropeAids/137266/BH/SER/ME. Podgorica, Banja Luka, Beograd, 166 pp. [in Serbian].

Popov S., Miličić M., Diti I., Marko O., Sommaggio D., Markov Z. \& VUJIĆ A. 2017: Phytophagous hoverflies (Diptera: Syrphidae) as indicators of changing landscapes. - Commun. Ecol. 18: $287-294$

Ricarte A., NedeljKović Z., Rotheray G.E., Lyszkowski R.M., Hancock G., Watt K., Hewitt S.M., Horsfield D. \& WilkinSON G. 2012: Syrphidae (Diptera) from the Greek island of Lesvos, with description of two new species. - Zootaxa 3175: $1-23$.

Ricarte A., Souba-Dols G.J., Hauser M. \& Marcos-García M.Á. 2017: A review of the early stages and host plants of the genera Eumerus and Merodon (Diptera: Syrphidae), with new data on four species. - PLoS ONE 12(12): e0189852, 22 pp.

Ricarte A., Nencioni A., KočIš Tubić N., Grković A., Vujić A. \& Marcos-García M.Á. 2018: The hoverflies of an oak Dehesa from Spain, with a new species and other insights into the taxonomy of the Eumerus tricolor group (Diptera: Syrphidae). Ann. Zool. 68: 259-280.

Rondani C. 1857: Dipterologiae Italicae prodromus. Vol: II. Species italicae. Pars prima. Oestridae: Syrpfhidae: Conopidae. A. Stocchi, Parmae [= Parma], 264 pp.

Rosser A.M. \& MaINKA S.A. 2002: Overexploitation and species extinctions. - Conserv. Biol. 16: 584-586.

Rotheray G.E. \& Gilbert F.S. 1999: Phylogeny of Palaearctic Syrphidae (Diptera): evidence from larval stages. - Zool. $J$. Linn. Soc. 127: 1-112.
Šs̆šić L., AČAnSki J., Vujić A., StÅhls G., Radenković S., Milić D., ObReht Vidaković D. \& Đan M. 2016: Molecular and morphological inference of three cryptic species within the Merodon aureus species group (Diptera: Syrphidae). - PLOS ONE 11(8): e0160001, 27 pp.

Sforzi A. \& Sommagio D. 2021: Catalog of the Diptera types described by Camillo Rondani. - Zootaxa 4989: 1-438.

SHEN Z. \& MA K. 2014: Effects of climate change on biodiversity. - Chin. Sci. Bull. 59: 4637-4638.

Simon C., Frati F., Beckenbach A., Crespi B., Liu H. \& Flook P. 1994: Evolution, weighting, and phylogenetic utility of mitochondrial gene sequences and a compilation of conserved polymerase chain reaction primers. - Ann. Entomol. Soc. Am. 87: 651-701.

SJöBerg F. 2015: The Fly Trap. Penguin Books, Random House, $278 \mathrm{pp}$.

Smit J.T., van Harten A. \& Ketelaar R. 2017: Order Diptera, Family Syrphidae. The hoverflies of the Arabian Peninsula. In van Harten A. (ed.): Arthropod Fauna of the UAE. Dar Al Ummah, Abu Dhabi, pp. 572-612.

SMit J.T., ZeEgers T. \& DorJI P. 2020: A new species of Eumerus (Diptera, Syrphidae) from the Kingdom of Bhutan, the easternmost representative of the bactrianus subgroup. - ZooKeys 906: $141-151$.

Sommaggio D. 2007: Revision of Diptera Syrphidae in Bellardi's Collection, Turin. - Boll. Mus. Reg. Sci. Nat. Torino 24: 121-158.

Souba-Dols G.J., Ricarte A., Hauser M., Speight M. \& MarcosGarcía M.Á. 2020: What do Eumerus Meigen larvae feed on? New immature stages of three species (Diptera: Syrphidae) breeding in different plants. - Organisms Divers. Evol. 20: 267-284.

Speight M.C.D. 2020: Species accounts of European Syrphidae, 2020. Syrph the Net, the Database of European Syrphidae (Diptera), Vol. 104. Syrph the Net publications, Dublin, 314 pp.

SPeight M.C.D., Hauser M. \& Withers P. 2013: Eumerus narcissi Smith (Diptera, Syrphidae), presence in Europe confirmed, with a redescription of the species. - Dipterist Digest 20: $17-32$.

SsYMANK A. \& LAIR X. 2014: Observations and collections of hoverflies (Diptera: Syrphidae) in the Mercantour National Park, France, including a checklist. - Stud. Dipterol. 21: 95-153.

Ssymank A., Doczkal D., Rennwald K. \& Dziock F. 2011: Rote Liste und Gesamtartenliste der Schwebfliegen (Diptera: Syrphidae) Deutschlands. In Binot-Hafke M., Balzer S., Becker N., Gruttke H., Haupt H., Hofbauer N., Ludwig G., MatzkeHajek G. \& Strauch M. (eds): Die Rote Liste gefährdeter Tiere, Pflanzen und Pilze Deutschlands, Band 3: Wirbellose Tiere (Teil 1). Landwirtschaftsverlag, Münster, pp. 13-83.

Stackelberg A.A. 1960: New Syrphidae (Diptera) from the Caucasus. - Entomol. Obozr. 39: 438-449.

StÅhls G., Vujić A., Pérez-Bañón C., Radenković S., Rojo S. \& Petanidou T. 2009: COI barcodes for identification of Merodon hoverflies (Diptera, Syrphidae) of Lesvos Island, Greece. Mol. Ecol. Resour. 9: 1431-1438.

Standfuss K. \& Claussen C. 2007: Zum aktuellen Artenbestand der Schwebfliegen (Diptera, Syrphidae) in der Ölbaumzone SO-Thessaliens/Griechenland. - Volucella 8: 147-164.

StĂNescu C. \& PÂrvu C. 2005: Syrphids (Diptera: Syrphidae) of Romania. Checklist, phenology, distribution. - Trav. Mus. Natl. Hist. Nat. Gr. Antipa 48: 177-202.

THOMPson C.F. 1999: A key to the genera of the flower flies (Diptera: Syrphidae) of the Neotropical Region including descrip- 
tions of new genera and species and a glossary of taxonomic terms. - Contrib. Entomol. Int. 3: 319-378.

Thompson J.D., Higgins D.G. \& Gibson T.J. 1994: Clustal W: improving the sensitivity of progressive multiple sequence alignment through sequence weighting, position-specific gap penalties and weight matrix choice. - Nucl. Acids Res. 22 4673-4680.

Tulloch A.I., Barnes M.D., Ringma J., Fuller R.A. \& Watson J.E. 2016: Understanding the importance of small patches of habitat for conservation. - J. Appl. Ecol . 53: 418-429.

Van Steenis W., De Groot M. \& Van Steenis J. 2013: New data on the hoverflies (Diptera: Syrphidae) of Slovenia. - Acta Entomol. Sloven. 21: 131-162.

Van Steenis J., Hauser M. \& van ZuiJen M.P. 2017: Review of the Eumerus barbarus species group (Diptera: Syrphidae) from the western Mediterranean Basin. - Bonn Zool. Bull. 66: $145-165$.

VuJić A. \& ŠImIĆ S. 1995-1998: Genus Eumerus Meigen 1822 (Diptera: Syrphidae) in area of former Jugoslavia. - Glasn. Prir. Muz. Beogradu 49-50: 173-190.

Vujić A., Petanidou T., Tscheulin T., Cardoso P., Radenković S., Stahls G., Baturan Ž., Mijatović G., Rojo S., Pérez-Bañón C. ET AL. 2016: Biogeographical patterns of the genus Merodon Meigen, 1803 (Diptera: Syrphidae) in islands of the eastern
Mediterranean and adjacent mainland. - Insect Conserv. Divers. 9: 181-191.

Vujić A., Šımić S. \& Radenković S. 2001: Endangered species of hoverflies (Diptera: Syrphidae) on the Balkan Peninsula. Acta Entomol. Serb. 5: 93-105.

Vujić A., Tot T., Andrić A., AČAnski J., Šašić Zorić L., PéreZBañón C., Aracil A., Veselić S., AroK M., Mengual X., van Eck A., RoHo S. \& Radenković S. 2021: Review of the Merodon natans group with description of a new species, a key to the adults of known species of the natans lineage and first descriptions of some preimaginal stages. - Arthr. Syst. Phylog. 79: $343-378$.

Wintle B.A., Kujala H., Whitehead A., Cameron A., Veloz S., Kukkala A., Moilanen A., Gordon A., Lentini P.E., CadenHEAD N.C.R. ET AL. 2019: Global synthesis of conservation studies reveals the importance of small habitat patches for biodiversity. — Proc. Natl. Acad. Sci. 116: 909-914.

Worboys G., Francis W.L. \& Lockwood M. 2010: Connectivity Conservation Management: A Global Guide (With Particular Reference to Mountain Connectivity Conservation). Earthscan, London, $381 \mathrm{pp}$.

Received April 29, 2021; revised and accepted October 29, 2021 Published online December 6, 2021

Table S1 on the following page. 
Table S1. List of genetically analysed samples with GenBank accession numbers (sequences newly generated herein are in boldface). Outgroup species asterisked. Sequences retrieved from GenBank were published in Grković et al. (2015, 2017), Šašić et al. (2016), Chroni et al. (2018) and Ricarte et al. (2018).

\begin{tabular}{|c|c|c|c|c|c|c|c|}
\hline $\begin{array}{c}\text { DNA } \\
\text { labcode } \\
\text { ID }\end{array}$ & $\begin{array}{c}\text { Database ID } \\
\text { specimen } \\
\text { voucher }\end{array}$ & Species & $\begin{array}{l}\text { Eumerus } \\
\text { species } \\
\text { group }\end{array}$ & Locality & Sex & $\begin{array}{l}\text { GenBank } \\
\text { acc. no. } \\
\text { (COI-5') }\end{array}$ & $\begin{array}{l}\text { GenBank } \\
\text { acc. no. } \\
\text { (COl-3') }\end{array}$ \\
\hline MS39 & FSUNS: G1362 & Xanthograma citrofasciatum (De Geer, 1776)* & & Serbia (RS), Dubašnica & o & KU365484 & KU365420 \\
\hline Y1778 & MZH: Y1778 & Archimicrodon sp. ${ }^{*}$ & & South Africa (ZA), Royal Natal & $\hat{0}$ & KU365483 & KU365419 \\
\hline TS327 & FSUNS: 11593 & Eumerus sogdianus Stackelberg, 1952 & strigatus & Greece (EL), Peloponnese & 01 & MG604935 & MZ604663 \\
\hline TS241 & FSUNS: 06724 & Eumerus minotaurus Claussen \& Lucas, 1988 & minotaurus & Greece (EL), Crete & q & KY865467 & KY865521 \\
\hline EU10 & FSUNS: G1147 & Eumerus alpinus Rondani, 1857 & alpinus & Italy (IT), Toscana & q & KX083349 & KY865493 \\
\hline EU11 & FSUNS: G3002 & Eumerus sulcitibius Rondani, 1868 & barbarus & Greece (EL), Andros & 01 & MG560025 & MZ604664 \\
\hline EU63 & FSUNS: 0863 & Eumerus pusillus Loew, 1848 & basalis & Greece (EL), Chios & 01 & MG559994 & MZ604665 \\
\hline EU82 & FSUNS: G3005 & Eumerus pulchellus Loew, 1848 & pulchellus & Greece (EL), Rhodes & 01 & MG559958 & MZ604666 \\
\hline EU92 & FSUNS: G3014 & Eumerus clavatus Becker, 1923 & clavatus & Serbia (RS), Pčinja & $\hat{0}$ & KX083350 & MZ604667 \\
\hline EU99 & FSUNS: G2219 & Eumerus ornatus Meigen, 1822 & ornatus & Montenegro (ME), Boka Kotorska & $\hat{0}$ & KY865449 & MZ604668 \\
\hline EU6 & FSUNS: G0955 & Eumerus niveitibia Becker, 1921 & tricolor & Bulgaria (BG), Nessebar & 01 & MG604931 & MZ604669 \\
\hline EU135 & FSUNS: G3018 & Eumerus tricolor (Fabricius, 1798) & tricolor & Italy (IT), Baragazza & q & KY865450 & KY865500 \\
\hline TS328 & FSUNS: 11542 & Eumerus tricolor (Fabricius, 1798) & tricolor & Greece (EL), Corfu & 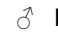 & MZ644021 & MZ643996 \\
\hline TS334 & FSUNS: 11528 & Eumerus tricolor (Fabricius, 1798) & tricolor & Greece (EL), Corfu & q & MZ644022 & MZ643997 \\
\hline EU5 & FSUNS: G0293 & Eumerus grandis Meigen, 1822 & tricolor & Serbia (RS), Đerdap & 01 & MG604930 & MZ604670 \\
\hline EU217 & FSUNS: G0267 & Eumerus grandis Meigen, 1822 & tricolor & Montenegro (ME), Orjen & $\hat{o}$ & MZ644023 & MZ643998 \\
\hline EU219 & FSUNS: G1956 & Eumerus grandis Meigen, 1822 & tricolor & Serbia (RS), Đerdap & 우 & MZ644024 & MZ643999 \\
\hline EU137 & FSUNS: G3019 & Eumerus grandis Meigen, 1822 & tricolor & Montenegro (ME), Durmitor & o & MZ644025 & MZ644000 \\
\hline EU429 & FSUNS: 7527 & Eumerus grandis Meigen, 1822 & & Montenegro (ME), Durmitor & $\hat{0}$ & MZ644026 & MZ644001 \\
\hline TS643 & & Eumerus grandis Meigen, 1822 & tricolor & Greece (EL), Konitsa & 0 & MZ644027 & MZ644002 \\
\hline EU127 & FSUNS: G3015 & Eumerus ovatus Loew, 1848 & tricolor & Italy (IT), Cunettone & 01 & MG604933 & MZ604671 \\
\hline EU128 & FSUNS: G3016 & Eumerus ovatus Loew, 1848 & tricolor & & $\hat{\sigma}$ & MZ644028 & MZ644003 \\
\hline EU129 & FSUNS: G3017 & Eumerus ovatus Loew, 1848 & tricolor & Italy (IT), Cunettone & 우 & MZ644029 & MZ644004 \\
\hline EU125 N & 1-UAegean: G2735 & Eumerus sinuatus Loew, 1855 & tricolor & Serbia (RS), Fruška gora & 01 & MG604932 & MZ604672 \\
\hline EU220 & FSUNS: G0273 & Eumerus sinuatus Loew, 1855 & tricolor & Serbia (RS), Fruška gora & $\hat{o}$ & MZ644030 & MZ644005 \\
\hline EU486 & FSUNS: 08003 & Eumerus tenuitarsis Grković \& Vujić, 2019 & tricolor & Turkey (TR), Isparta & 우 & MZ644031 & MZ644006 \\
\hline EU487 & FSUNS: 08002 & Eumerus tenuitarsis Grković \& Vujić, 2019 & & Turkey (TR), Isparta & q & MZ644032 & MZ644007 \\
\hline EU138 & FSUNS: G2279 & Eumerus aurofinis Grković, Vujić \& Radenković, 2015 & tricolor & Greece (EL), Samos & $\hat{0}$ & MZ644033 & MZ644008 \\
\hline EU213 & FSUNS: G1785 & Eumerus aurofinis Grković, Vujić \& Radenković, 2015 & tricolor & Greece (EL), Samos & q & KT221009 & MZ604673 \\
\hline EU289 & FSUNS: 06748 & Eumerus aurofinis Grković, Vujić \& Radenković, 2015 & tricolor & Greece (EL), Rhodes & q & MZ644034 & MZ644009 \\
\hline TS330 & FSUNS: 11480 & Eumerus nigrorufus Grković \& Vujić, sp. n. & tricolor & Montenegro (ME), Durmitor & q & MZ644035 & MZ644010 \\
\hline TS331 & FSUNS: 11481 & Eumerus nigrorufus Grković \& Vujić, sp. n. & tricolor & Montenegro (ME), Durmitor & q & MZ644036 & MZ644011 \\
\hline TS332 & FSUNS: 11482 & Eumerus nigrorufus Grković \& Vujić, sp. n. & tricolor & Montenegro (ME), Durmitor & $\hat{o}$ & MZ644037 & MZ644012 \\
\hline TS333 & FSUNS: 11483 & Eumerus nigrorufus Grković \& Vujić, sp. n. & tricolor & Montenegro (ME), Durmitor & o 1 & MZ644038 & MZ644013 \\
\hline EU7 & FSUNS: G1014 & Eumerus armatus Ricarte \& Rotheray, 2012 & tricolor & Greece (EL), Samos & $\hat{0}$ & MG559898 & MZ604674 \\
\hline EU222 & FSUNS: G1775 & Eumerus armatus Ricarte \& Rotheray, 2012 & tricolor & Greece (EL), Samos & 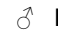 & MZ644039 & MZ644014 \\
\hline EU223 & FSUNS: G1020 & Eumerus armatus Ricarte \& Rotheray, 2012 & tricolor & Greece (EL), Samos & $\hat{0}$ & KY865456 & KY865506 \\
\hline EU224 & FSUNS: 1789 & Eumerus armatus Ricarte \& Rotheray, 2012 & tricolor & Greece (EL), Samos & $\hat{0}$ & MZ644040 & MZ644015 \\
\hline EU292 & FSUNS: 06740 & Eumerus armatus Ricarte \& Rotheray, 2012 & tricolor & Greece (EL), Rhodes & $0^{2}$ & MZ644041 & MZ644016 \\
\hline EU294 & FSUNS: 06747 & Eumerus armatus Ricarte \& Rotheray, 2012 & tricolor & Greece (EL), Rhodes & $0^{2}$ & MZ644042 & MZ644017 \\
\hline 11316 & FSUNS: 11316 & Eumerus armatus Ricarte \& Rotheray, 2012 & tricolor & Greece (EL), Lesvos & q & MZ644043 & MZ644018 \\
\hline TS877 & FSUNS: 26421 & Eumerus armatus Ricarte \& Rotheray, 2012 & tricolor & Cyprus (CY), Kyrenia & $\hat{0}$ & MZ644044 & MZ644019 \\
\hline TS871 & FSUNS: 25651 & Eumerus crispus Vujić \& Grković, sp. n. & tricolor & Serbia (RS), Fruška gora & 0 & MZ644045 & MZ644020 \\
\hline
\end{tabular}

